\title{
Creditor Control Rights and Managerial Risk Shifting
}

\author{
Burcu Esmer*
}

December 2012

\begin{abstract}
Recent evidence shows that corporate policies change significantly following financial covenant violations. These changes are attributed to increased creditor influence over borrowing firms in ways that benefit both shareholders and debtholders. In this paper, I investigate whether shareholders engage in activities counter to creditors' interests following violations. I find that the expected negative relation between volatility and investment reverses for firms once they violate a covenant, consistent with risk-shifting behavior. This behavior is more pronounced in firms with high CEO portfolio sensitivity to stock return volatility and firms with high CEO equity ownership. Moreover, I document a significant increase in firm risk in the year following the violation. Overall, these findings suggest that even in the presence of increased creditor control risk shifting still occurs. The prior conclusions that shareholder-debtholder incentives are congruent at violations do not appear to be the case.
\end{abstract}

JEL Classification: G32, J33

Key words: Debt covenants, risk shifting, agency conflicts, investment, managerial incentives

\footnotetext{
*Faculty of Business Administration, Bilkent University. e-mail: besmer@bilkent.edu.tr , tel: +90 (312) 290-1041. I am grateful for helpful comments and suggestions by Andrew A. Acito, Matthew T. Billett, Fabio Braggion, Phil Davies, Redouane Elkamhi, Jon A. Garfinkel, Julapa Jagtiani, Erik Lie, Greg Nini, María Fabiana Penas, Michael Roberts, David Mauer, Ashish Tiwari, Anand Vijh and seminar participants at The University of Iowa, Tilburg University, The University of Texas at Dallas, Aalto University, Bocconi University, Catholic University of Portugal at Lisbon, Sabanci University, Ozyegin University, Bilkent University, California State University at Fullerton, The Netherlands Network of Economics (NAKE) Conference, The Financial Management Association 2010 Meeting, and Midwest Finance Association 2011 Meeting. I thank Greg Nini, David C. Smith and Amir Sufi for providing access to their covenant violations data. The earlier drafts have been circulated under the title "Are creditors able to control managerial risk shifting after covenant violations?"
} 
Recent empirical corporate finance literature documents a significant change in borrowing firms' investment, financial and payout policies following the violation of financial covenants in private debt agreements. As argued by Chava and Roberts (2008) and Roberts and Sufi (2009), once financial covenants are violated (other than through payment defaults), creditors obtain the right to accelerate any outstanding principal and withhold further credit. Although creditors almost always waive the violation, the threat associated with these rights enables creditors to exert significant influence over the firm. For instance, Nini, Smith, and Sufi (2012) show that violations are followed by decreased investment spending, reduced net debt issuance, lower leverage, and lower shareholder payouts. ${ }^{1}$ These findings are attributed to increased creditor influence on the borrowing firm in ways that would benefit both debtholders and shareholders.

Nini, Smith, and Sufi (2012) conclude that the shift in control rights to creditors "has a positive knock-on effect that benefits shareholders even as the creditors move to protect their own claims" (page 1758). The literature has not investigated, however, actions taken by managers (who are acting on behalf of shareholders) that may be counter to creditor interests. This paper fills this gap by examining the risk-shifting behavior of managers around covenant violations.

Jensen and Meckling (1976) introduce risk shifting as a source of shareholder-debtholder conflicts and argue that shareholders may extract wealth from debtholders by switching from

\footnotetext{
${ }^{1}$ Chava and Roberts (2008) and Nini, Smith, and Sufi (2009) show a reduction in investment spending following violations. Roberts and Sufi (2009) study changes in financial policy following violations and show a reduction in net debt issuance and leverage ratio. Nini, Smith, and Sufi (2012) document a decrease in shareholder payouts. In addition, Nini et al. (2012) show an increase in CEO turnover, hiring of turnaround management and corporate restructuring following violations. Nini et al. (2012) and Demiroglu and James (2010) show that stock price performance and operating performance improve following violations.
} 
safer to riskier investments. A large body of work examines various features of debt contracts (including covenants, maturity, and optionality) to see whether they alleviate shareholderdebtholder conflicts (Johnson (2003), Bradley and Roberts (2004), Billett, King, and Mauer (2007)). While these features appear to relate to firm characteristics (e.g. growth opportunities and leverage), little is known about their direct influence on firm behavior on an ongoing basis. ${ }^{2}$

Covenant violations present a unique opportunity to examine agency conflicts between shareholders and debtholders for three reasons. First, violations may signal deterioration in firm condition. ${ }^{3}$ If so, these firms are more likely to engage in risk-shifting behavior (Fang and Zhang (2004), Larsen (2006)). Second, covenant violations often follow long and arduous renegotiations, suggesting that reconciliation is difficult and conflicts between creditors and shareholders are not easily resolved. Third, given creditors increased influence over borrowing firms following violations, shareholders may counter creditors' actions by, for example, investing in risky projects.

To empirically examine whether shareholder decisions following covenant violations are driven by agency conflicts, I study the relation between uncertainty and firm investment. Covenant violations are associated with increased uncertainty. According to the real-options literature, absent agency conflicts, increased uncertainty raises managers' incentives to delay investment. The delay allows them to obtain more information on projects and avoid potentially

\footnotetext{
${ }^{2}$ The static models used in the literature assume the relation between these features and firm characteristics to be fixed over time. An alternative approach is to use a dynamic model and look at changes in firm behavior once the debt is in place.

${ }^{3}$ Beneish and Press $(1993,1995)$ and Wilkins (1997) argue that technical violations are associated with an increased likelihood of financial distress. Dichev and Skinner (2002), however, point out that technical violations are not always associated with financial distress.
} 
large losses by discontinuing unprofitable projects. ${ }^{4,5}$ It has been widely shown that the relation between investment and uncertainty is negative in healthy firms (see, for instance, McDonald and Siegel (1986)). ${ }^{6}$ However, in firms where shareholder-debtholder agency conflicts are severe, this relationship is less negative or even positive (see Mauer and Sarkar (2005) and Eisdorfer (2008)). When managers have incentives to engage in risk-shifting activities, increased uncertainty provides an opportunity for managers to increase equity value through investment in risky projects. In this case, high uncertainty encourages acceleration of investment beyond the first-best level, weakening the negative relation between investment and risk. Eisdorfer (2008) models and empirically documents the existence of the risk-shifting problem by showing that negative relation between uncertainty and investment becomes less negative (even positive) as firms approach high probability of default. Consistent with the existence of agency conflicts, I show that the negative relation between investment and uncertainty reverses for firms following a covenant violation. ${ }^{7,8}$

\footnotetext{
${ }^{4}$ This is consistent with the argument that managers are likely to undertake new projects that are below optimal risk. See Low (2009), Amihud and Lev (1981), Smith and Stulz (1985), Williams (1987).

${ }^{5}$ Instead of timing the investment, managers may forego the investment altogether. For instance, Minton and Schrand (1999) argue that firms experiencing shortfalls forgo investment.

${ }^{6}$ See also Pindyck (1988), Pindyck and Solimano (1993), Dixit and Pindyck (1994), Episcopos (1995), Caballero and Pindyck (1996), Ghosal and Loungani (1996), Leahy and Whited (1996), Trigeorgis (1996), Bulan (2003), Stein and Stone (2010).

${ }^{7}$ An alternative explanation for the positive correlation between uncertainty and investment is that firms may accelerate investment when there is uncertainty about firms' future financing abilities. For instance, Boyle and Guthrie (2003) argue that the threat of future funding shortfalls reduces the value of firms' timing options and leads to sub-optimal early investment. Even controlling for firms' financial health (proxied by Whited and Wu (2006) index) leaves an economically and statistically significant positive relation between volatility and investment in my analysis.

${ }^{8}$ Prior literature on covenant violations raises concerns about a potential sample selection problem. Following Nini et al. (2012), I use a "quasi-discontinuity" approach similar to the one in Roberts and Sufi (2009) in all tests. This way I hope to compare the investment-risk relation of firms which violate a covenant relative to firms which do not violate a covenant in the same quarter with a similar pre-violation pattern. In each regression, I include linear and
} 
To explore whether risk-shifting behavior changes around violations, I study the volatility-investment relation for one-time only violators before and after the violation. I find that the relation between volatility and investment reverses around covenant violations. Higher uncertainty is associated with lower investment before violations, consistent with managers following the first-best option and delaying the investment. In the year of the violation; however, uncertainty is positively associated with investment, consistent with risk shifting.

I further study whether agency conflicts indeed explain the change in the investment-risk relation around covenant violations by investigating CEO incentives. If risk-shifting is driving this result, I expect the effect to be more pronounced in firms with CEO incentives to take on risk. Previous work suggests equity-based executive compensation induces managers to take more risk, thus better aligning manager and shareholder interests. ${ }^{9}$ Large managerial stock ownership and high CEO wealth sensitivity to stock return volatility (vega) provides executives with incentives to implement policy choices that increase risk (Brockman, Martion, and Unlu (2009)). ${ }^{10}$ Higher CEO wealth sensitivity to stock prices (delta), in contrast, gives a risk-averse manager an incentive to avoid risk (Chava and Purnanandam (2010)). ${ }^{11}$ Consistent with the literature, I find that managers with higher stock ownership and managers whose wealth is more

higher order control variables (squared and cubic terms) on which financial covenants are written. I also control for changes in these control variables before and after a violation. This way, I hope to identify the effect of violations separately from the expected changes in outcomes driven by the performance of violators. Further, I use a firstdifference specification to control for the expected time-series path of outcomes following negative firm performance. I also use a matching firm procedure to control for the size and book-to-market effects. The results are robust to this alternative methodology.

${ }^{9}$ Agrawal and Mandelker (1987) and Datta, Iskandar-Datta, and Raman (2001) provide such evidence for industrial firms, Rajgopal and Shevlin (2001) for oil and gas producers, and Saunders, Strock, and Travlos (1990) for banks.

${ }^{10}$ See also Smith and Stulz (1985), Guay (1999), Cohen, Hall, and Viceira (2000), Coles, Daniel, and Naveen (2006).

${ }^{11}$ See also Knopf, Nam, and Thornton (2002), Brockman, Martin and Unlu (2009). 
sensitive to changes in stock volatility (higher vega) engage in more risk-shifting activities, whereas high delta is associated with less risk-shifting.

Finally, I examine firm risk around violations. If risk shifting is occurring then we would expect firm risk to increase. ${ }^{12}$ Using a "quasi-discontinuity" design to isolate the effect of the violation on firm risk, I show a significant $5 \%$ increase in risk over the industry median in the year following violations. Moreover, the increase is persistent, lasting over two years after the violation. The main measure is asset volatility calculated using Moody's KMV method (e.g. Vassalou and Xing (2004)). I also use alternative proxies for risk including total equity risk, systematic and unsystematic risk (calculated from the market model), asset beta, and volatility of earnings to alleviate concerns that the results are sensitive to the measure of risk. The increase in risk following violations using these alternative measures varies from $8 \%$ to $15 \%$ and is statistically significant.

The main contribution of this study is to the growing body of literature on the effect of covenant violations on financial, capital structure, and payout policies of firms (Beneish and Press (1993, 1995), Chen and Wei (1993), Dichev and Skinner (2002), Chava and Roberts (2008), Nini et al. $(2009,2012)){ }^{13}$ These studies argue that creditors exert influence over borrowing firms following violations to protect their own interests. Nini et al. $(2009,2012)$

\footnotetext{
${ }^{12}$ There are obviously other explanations why firm risk increases so this evidence is seen as consistent but not entirely conclusive of risk shifting.

${ }^{13}$ I study private credit agreements rather than public bonds for several reasons. First, private debtholders have superior monitoring ability since they govern the terms of sole-lender and syndicated bank loans to companies. Second, these agreements include more detailed, comprehensive, and tighter covenants. These covenants are more binding for borrowers which are typically small, growing firms (Malitz (1986)), which are more likely to engage in risk-shifting activities (Fang and Zhong (2004), Larsen (2006)). Lastly, violations of private debt covenants are more common. Nearly 40 percent of firms are in violation at some point during 1996 through 2007.
} 
conclude that shareholders and debtholders may have common interests and restrictions put by creditors can also benefit shareholders. My paper questions this argument and show that even in the presence of increased creditor monitoring, risk-shifting occurs. ${ }^{14}$ This suggests that the conclusion that shareholder-debtholder incentives are congruent does not appear to be the case. ${ }^{15}$

This study also contributes to the applied financial contracting literature that focuses on the implications of covenants for agency conflicts (Smith and Warner (1979), Malitz (1986), Hart (1995), Tirole (2006), Billett et al., (2007), Fu and Zhang (2011)). The presence of covenants in financial contracts is motivated and rationalized by their ability to mitigate the conflicts between shareholders and debtholders. ${ }^{16}$ In this paper, I show that financial covenants may help alleviate worse problems absent covenant violations; however, they do not fully prevent the problem.

Another important contribution of this paper is to the theoretical and empirical literature on risk shifting. Although a large number of studies theoretically analyze the implications of the risk-shifting problem, the evidence on the existence of the problem is mixed. Andrade and Kaplan (1998), De Jong and Van Dijk (2001), and Graham and Harvey (2001) examine riskshifting and find little or no evidence. Fang and Zhong (2004) and Larsen (2006) study asset risk

\footnotetext{
${ }^{14}$ Another argument is that observed changes in firm behavior following violations are not driven by creditor actions (see Demiroglu and James, (2010)).

15 One may argue that debtholders are willing to renegotiate covenants as long as they are ex ante paid for ex post wealth transfer. In this case debtholders protect themselves by repricing the debt and shareholders bear the ex ante costs. When debtholders do not anticipate risk shifting behavior from borrowing firms, they bear the costs related to risk shifting. For instance, Pryshchepa et al. (2012) show that distressed firms that manage to conceal their health issues can raise new funding without strict covenants and use this fund to shift risk.

${ }^{16}$ Covenants may not be as effective in mitigating risk shifting due to incomplete contracting (Grossman and Hart, 1986; Hart and Moore, 1988 \& 1990; Hart, 1995; Tirole, 1999).
} 
and find evidence of risk shifting among industrial firms. Eisdorfer (2008) recently provided evidence of risk shifting in financially distressed firms by studying investment-risk relationship. Eisdorfer (2008) relates firm characteristics (financial health) to agency conflicts. My paper, however, investigates changes in investment behavior and firm risk around covenant violations. The evidence of risk shifting in firms which violate covenants is especially interesting since these firms are not necessarily financially distressed.

The rest of the paper proceeds as follows. The next section provides background on related literature. Section II discusses the data, variable definitions, summary statistics and methodology. Section III presents the results. Section IV discusses robustness checks and Section V concludes.

\section{Related literature}

\section{I.A. Financial covenants: Background}

Financial covenants consist of restrictions that do not allow certain balance sheet items or ratios to fall below or exceed an agreed upon limit. These covenants can include restrictions on a firm's leverage, interest coverage, total fixed charges (including, for example, interest, rent, and capital expenditures), and net worth. Once covenants are violated, creditors receive the right to accelerate the outstanding principal and to terminate any unused revolving debt (Aghion and Bolton (1992), Dewatripont and Tirole (1994)). Although creditors often waive violations, they protect their financial claims through bargaining that occurs around the waiver. The actions creditors can take includes but not limited to: tightening constraints on existing credit agreements 
(by increasing interest rates, reporting requirements and collateral requirements), and extracting amendment fees (Gopalakrishnan and Parkash (2005)).

A number of recent studies investigate violations of financial covenants in private debt agreements and their effect on firm policies. Chava and Roberts (2008) and Nini et al. (2009) show a sharp decrease in investment following violations. Roberts and Sufi (2009) find that firms violating covenants significantly decrease their net debt issuing activity, which decreases their leverage ratios. Nini et al. (2012) confirm these results and also show that violations are followed by a decrease in shareholder payouts, an increase in CEO turnover, an increase in the incidence of corporate restructurings, and an increase in the likelihood of hiring turnaround specialists. These studies attribute the changes in firm behavior following violations to increased creditor control over the borrowing firm.

\section{I.B. Covenants and agency conflicts}

A number of studies in the optimal contracting literature examine security design models where covenants define the circumstances under which creditors are permitted to intervene in management (e.g. Aghion and Bolton (1992), Dewatripont and Tirole (1994)). In such instances, the transfer of decision rights can be seen as a corporate governance mechanism to prevent "bad" managers from making value-reducing decisions following poor performance (due to, for instance, low effort and risk-shifting), but well before bankruptcy. These theories view potential agency conflicts arising between managers and external investors (shareholders and debtholders), not between manager-shareholders and debtholders. Consistent with this view, 
Nini et al. (2009, 2012) conclude that creditor intervention following violations benefit shareholders, by constraining managerial value-reducing overinvestment.

In this paper, I focus on agency conflicts between shareholders and debtholders, and study whether shareholders engage in actions that are counter to debtholders' interests following financial covenant violations. Covenant violations present a unique opportunity to examine shareholder-debtholder agency conflicts for several reasons. First, the existence of covenants is motivated and rationalized by their ability to mitigate conflicts such as dividend payment, claim dilution, risk shifting, and underinvestment (Smith and Warner, 1979). ${ }^{17}$ Consistent with theoretical predictions, Malitz (1986) shows that firms with high shareholder-debtholder conflicts are more likely to include covenants in debt contracts. Billett, King, and Mauer (2007) find a positive relation between covenant protection in public debt contracts and growth opportunities using a simultaneous-equation model. Hjortsho and Wei (2009) investigate public debt contracts and show that firms with more detailed covenants have lower risk. Similarly, Bradley and Roberts (2004), and Demiroglu and James (2008) study private debt agreements and find positive relation between growth opportunities and covenant protection. Fu and Zhang (2011) show that firms with more restrictive covenants in private debt agreements spend less on R\&D, diversify more, and their CEOs have less risk-taking incentives from option compensation.

Second, violations may signal deterioration in a borrowing firm's condition. Beneish and Press (1993, 1995) and Wilkins (1997) argue that financial covenant violations are associated

\footnotetext{
${ }^{17}$ See also Myers (1977), Smith (1993), Hart (1995), Tirole (2006).
} 
with an increased likelihood of financial distress. ${ }^{18}$ Third, given creditors increased influence over borrowing firms following violations, shareholders may counter creditors' actions by, for example, investing in risky projects. Lastly, covenant violations often follow long and arduous renegotiations, suggesting that conflicts between creditors and shareholders are not easily resolved.

\section{I.C. Evidence on risk shifting}

One of the important sources of conflicts between shareholders and debtholders is the risk-shifting problem (Jensen and Meckling (1976) and Myers (1977)). When firms are indebted, investments or transactions that increase cash flow volatility also increase the value to shareholders of their call option on the firm's assets, causing devaluation of debt. Although a large number of studies theoretically analyze the implications of risk-shifting, there is little evidence on the existence of the problem. Andrade and Kaplan (1998) study investment activities of 31 financially distressed firms and find no evidence of risk-shifting. De Jong and Van Dijk (2001), and Graham and Harvey (2001) examine the risk-shifting incentives using surveys and find little or no evidence. Esty (1997) finds that risk shifting was significant in the savings and loan industry during the 1980s. More recently, Laeven and Levine (2009) provide evidence of risk shifting in banks. Fang and Zhong (2004), and Larsen (2006) document evidence of risk shifting among industrial firms by showing that financially distressed firms are more likely to have high asset volatility.

\footnotetext{
${ }^{18}$ Dichev and Skinner (2002), however, report that financial covenant violations are not always associated with financial distress.
} 
Large sample evidence of risk-shifting is recently provided by Eisdorfer (2008) using a real options framework. Under the real options logic, a firm's investment decision involves a tradeoff between delaying investment to obtain more information about a project's value, and realizing early cash flows by investing in the project immediately. The value of delaying the investment increases with the degree of uncertainty about a project's cash flows. Therefore, absent agency conflicts, investment is expected to decrease when uncertainty increases (e.g. McDonald and Siegel (1986)). The empirical evidence generally supports the negative relation between investment and volatility (see Panousi and Papanikolaou (2009), Baum, Caglayan and Talavera (2008), Bulan (2005), Leahy and Whited (1996), Dixit and Pindyck (1994)).

In firms where shareholder-debtholder conflicts are severe; however, this relationship becomes less negative or even positive. When managers have incentives to engage in riskshifting activities, increased uncertainty decreases the value of waiting and provide an opportunity for managers to increase equity value by investing in risky projects. In this case, increased uncertainty encourages acceleration of investment beyond the first-best level (see Mauer and Sarkar (2005)). Eisdorfer (2008) models and shows that in financially distressed firms, high uncertainty has a positive effect on investment, consistent with the risk-shifting argument. $^{19}$

\section{Data and variable definitions}

\footnotetext{
19 Please see Appendix A for a brief explanation of Eisdorfer's (2008) model.
} 
Covenant violations data is obtained from Amir Sufi's website. ${ }^{20}$ The sample construction below follows Nini et al. (2012) using the period 1996 through 2007. To be included in the sample, I require firms to be U.S. (fic="USA") public firms and to have data available on the Compustat and Center for Research in Security Prices (CRSP) databases. I exclude financial firms (SIC 6000-6999) and utilities (SIC 4900-4999) because these firms are often subject to heavy federal regulations. I exclude firms with missing information on total assets, sales, common shares outstanding, closing share price, and the calendar quarter of the filing. Finally, I require firms to be publicly traded with ordinary common shares (CRSP share code 10 or 11: thus I exclude ADRs, REITs, units, certificates, and trusts). Imposing these restrictions leaves a sample of 9,915 firms and 233,398 firm-quarter observations. I follow Nini et al. (2009) and focus my analysis on new financial covenant violations, which are defined as financial covenant violations for firms that have not violated a covenant in the previous four quarters.

\section{A. Variable definitions}

This section describes the construction of each measure including firm risk, investment and managerial risk taking incentives. For variable definitions of control variables, please see Appendix B.

\footnotetext{
${ }^{20}$ This data is available at http://faculty.chicagobooth.edu/amir.sufi/data.htm. Nini, Smith, and Sufi extract information from every 10-Q and 10-K filing on SEC Edgar website. Using a text-searching algorithm, they determine whether a firm is in violation of a covenant. Then they match this information to COMPUSTAT file. For more information on the data, please see Appendix of "Creditor Control Rights, Corporate Governance and Firm Value" by Nini, Smith and Sufi (2009).
} 
Total Investment. Following Coles, Daniel, and Naveen (2006) and Biddle, Hilary and Verdi (2009), I define Total Investment in a given fiscal end-year as the sum of capital expenditures, research and development $(\mathrm{R} \& \mathrm{D})$ expenditures, and acquisitions minus sales of plant, property and equipment (PPE), scaled by lagged total assets. An advantage of this approach is that it considers several types of investments such as capital expenditures and acquisitions as well as asset sales. It also considers $R \& D$ expenditure which has become an important investment item in the recent years.

Asset Volatility. I follow Fang and Zhong (2004), Larsen (2006), and Hjortshøj and Wei (2009) and use asset volatility to investigate risk shifting. To estimate asset volatility, I use Moody's KMV method (Crosbie and Bohn (2003)). In this model, equity is viewed as a call option on the value of the firm's assets (Merton (1974). The market value of equity is the number of shares outstanding multiplied by closing price at the end of the firm's fiscal year. The face value of the firm's debt (strike price) is set equal to the current liabilities plus half the long-term debt, $T$ equals one year, and $r$ is the one-year Treasury bill rate from Ken French's website. ${ }^{21,22,23}$

I follow Hillegeist, Keating, Cram, and Lundstedt (2004) and estimate the asset value and asset volatility by simultaneously solving the call option equation and the optimal hedge equation. The starting values are determined by setting value of assets equal to the book value of

\footnotetext{
${ }^{21}$ Fang and Zhong (2004), Vassalou and Xing (2004), and Hjortshøj and Wei (2009).

${ }^{22}$ It is important to add long-term debt for two reasons: the magnitude of long-term debt affects the ability of a firm to roll-over its short-term debt and firms need to service their long-term debt and their interest payments are part of their short-term debt (Vassalou and Xing (2004)).

23 As a robustness check, I follow Barclay and Smith (1995) who document that the median maturity of long-term debt is around five years, and assuming short-term debt follows a uniform distribution (i.e. median maturity is six months $)$, the firm's average debt maturity is estimated by: $\mathrm{T}=(0.5 *$ Short-Term Debt $+5 *$ Long-Term Debt $) /$ Total Debt. This estimation gives an average maturity is six years, which is consistent with previous literature. The results are robust to this maturity choice.
} 
liabilities plus the market value of equity and asset volatility equal to weighted value of equity volatility. Appendix C further explains the method.

Following Hjortshoj and Wei (2009), I calculate a risk adjustment ratio (RAR) to examine the change in risk following violations. RAR is the ratio between next year's asset volatility and this year's asset volatility $\left(\sigma_{A}{ }^{t+1}, \sigma_{A}{ }^{t}\right)$. Hence, when RAR in a given year is above (below) one, the firm subsequently increases (decreases) its business risk. In a given year, market conditions and business cycles may affect asset volatility. In order to filter out industrywide factors, I use an industry-adjusted risk adjustment ratio $\left(\operatorname{IRAR}_{\mathrm{t}}\right)$. IRAR is calculated by subtracting the industry median in the same year from each firm's RAR, where the industry definition is based on the two-digit SIC code. When IRAR is above (below) 0, the firm subsequently increases (decreases) its business risk relative to the industry peers.

Total risk, systematic risk, unsystematic risk. Total equity risk is a widely used equity risk indicator in finance research (see Goyal and Santa-Clara (2003)). I use the standard deviation of daily stock returns for the 252 trading days before the covenant violation to estimate total firm risk. I decompose total equity risk into systematic risk and unsystematic risk since managers can affect both the level of total risk and its components. Moreover, shareholders are especially interested in systematic risk since it cannot be eliminated through diversification. Parties that have business relations with violating firm are likely to be interested in unsystematic risk, given that violations may affect the borrowing firm's ability to satisfy existing contracts. I regress the same daily returns data for each firm against the CRSP equal-weighted market index and use the standard deviation of the errors in this regression as a measure of firms' unsystematic risk. 
Systematic risk is measured by the standard deviation of the firm beta times the daily market returns.

Asset Beta. Following Fargher, Wilkins, and Holder-Webb (2001), I use unlevered asset beta to measure change in business risk. I first calculate equity beta with a one-factor market model using daily returns for the 252 trading days before the violation, then I calculate asset betas by "unlevering" equity betas to remove the effects of leverage using market leverage. Equity beta reflects the combined effects of business and financial risk that the company faces with. Asset beta, however, is not confounded by financial risk.

Earnings Volatility. To ensure that the change in risk following violations is not determined by the change in stock prices, I use an accounting measure, earnings volatility, following Laeven and Levine (2009). I calculate earnings volatility as the standard deviation of a firm's return on asset (ROA) over 12 quarterly observations.

CEO Incentives. I use CEO portfolio vega and delta values to measure managers' incentives to change firm risk (Coles, Daniel, and Naveen (2006)). Vega is the dollar change in CEO option holdings for a one percent change in the annualized standard deviation of stock returns. Delta is the dollar gain in the manager's personal portfolio as the stock price goes up by one percent. I calculate vega and delta values using the Black-Scholes option valuation model outlined in Core and Guay (2002). Appendix D further describes the method. I also use percentage stock ownership of managers as an alternative measure of managerial incentives. The percentage of equity owned by the CEO is calculated using Execucomp database. 


\section{B. Summary statistics}

Table I shows the fraction of firms that violate a covenant in any given year from 1996 to 2007. Between ten and 17 percent of firms violate a covenant in a given year. Five to nine percent of firms experience a new violation in a given year. Not surprisingly, both violations and new violations follow a cyclical pattern and peak during the 2001 recession. $^{24}$

Table II displays the summary statistics for new violator firms and non-violator firms. ${ }^{25}$ Although the numbers vary between violators and non-violators, the median violator is not on the verge of payment default or bankruptcy and it is not experiencing a sharp liquidity shortage. Net worth scaled by assets for the median violator is 0.40 , and 0.50 for the median non-violator. Similarly, the current ratio (1.49) for new violators is lower than for non-violators (1.96). The median violator has reasonably high market to book ratio (1.18) compared to the median nonviolator (1.44). Not surprisingly, violator firms have higher leverage ratios and interest expense scaled by lagged assets compared to non-violators. The quarterly operating cash flow for the median violator is 0.01 which is close to the median non-violator number of 0.03 . The median violator has an $\mathrm{S} \& \mathrm{P}$ issuer credit rating of $\mathrm{BB}$ and a $\mathrm{Z}$-score of 1.95 , consistent with notion that firms experiencing a technical default are not on the verge of bankruptcy.

Panel B presents summary statistics for important organizational characteristics of

\footnotetext{
${ }^{24}$ In untabulated results, I find that around 38 percent of firm in my sample violate a financial covenant at some point during the sample period. This shows that violations are common among public firms. Most firms violate debt covenants only once (more than 50 percent). Less than 18 percent of firms violate covenants twice. The distribution of violations is similar across industries, but violations are most common in wholesale trade.

${ }^{25}$ A new covenant violation is a financial covenant violation by a firm that has not violated a covenant for the previous four quarters. A firm is included in the non-violation sample if it has not announced a new violation at that quarter.
} 
violator and non-violator firms. Consistent with Denis and Mihov (2003), the median violator is smaller, has fewer tangible assets, and has lower credit quality.

Panel C displays summary statistics for firm risk variables. The median annualized total equity risk (total unsystematic risk) is 72\% (70\%) for violators and 55\% (52\%) for nonviolators. $^{26}$ The median annualized systematic risk is $15 \%$ for violators and $14 \%$ for nonviolators. The equity beta and asset beta for non-violators are higher. The equity (asset) beta is $1.08(0.80)$ for non-violators and $1.01(0.54)$ for violators. The asset volatility calculated using Merton's model is 39\% for both violators and non-violators. On average, violators increase their asset risk by three percent from the previous year. Even adjusting for the industry, I show that the median violator increases its firm risk by four percent after the covenant violation. The sample median RAR for non-violators indicates that non-violators are reducing asset risk more than half of the time.

Panel D shows summary statistics for managerial risk taking incentives: Vega. For a one percentage point increase in the company's equity risk, there is a $\$ 22,279$ increase in CEO compensation for the median firm. This number is nearly three times larger for the median nonviolator firm.

\section{Estimation methods}

Following Nini et al. (2012), I use the first difference regression for continuous dependent variables:

\footnotetext{
${ }^{26}$ These estimates are higher compared to other studies. The difference arises from the time period used in this study. Equity volatility is particularly high in late 1990s and early 2000s.
} 
$\mathrm{y}_{\mathrm{i}, \mathrm{t}+4-\mathrm{y}_{\mathrm{i}, \mathrm{t}}=\boldsymbol{\beta}_{\mathbf{1}} * \text { Violation Dummy }} \mathbf{i , \mathrm { t }}+\Theta_{1} *$ Covenant Controls $_{\mathrm{i}, \mathrm{t}}+\Theta_{2} *$ Covenant Controls $_{\mathrm{i}, \mathrm{t}+4}-$

Covenant Controls $\left.\mathrm{i}_{\mathrm{i}, \mathrm{t}}\right)+\Theta_{3} *\left(\right.$ Covenant Controls $_{\mathrm{i}, \mathrm{t}}-$ Covenant Controls $\left._{\mathrm{i}, \mathrm{t}-\mathrm{4}}\right)+\Theta_{4} *($ Covenant

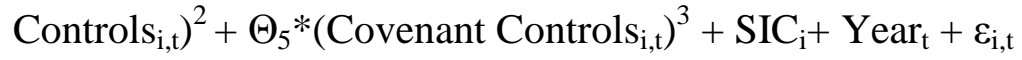

In this equation, Violation is an indicator variable that equals 1 for a new financial covenant violation, SIC represents one-digit SIC industry indicator variables, and Year represents year indicator variables, which is included because firm outcomes may change over time. ${ }^{27}$ To avoid overlapping observations, I restrict the sample to firm-quarter observations in the fourth quarter of each year. I use the fourth quarter since financial covenant violation announcements are more common in $10-\mathrm{K}$ filings than in $10-\mathrm{Q}$ filings. ${ }^{28}$

I include the most common ratios used in debt agreements in my analysis. These ratios include: operating cash flow to lagged assets, leverage (debt-to-assets), interest expense to lagged assets, net worth to assets, and the current ratio (current assets / current liabilities). I also include market-to-book ratio since it is a good predictor of firm performance. I call these variables as Covenant Controls and add these variables linearly, squared, and cubed to the specifications.

As pointed out by Roberts and Sufi (2009), violations may occur due to deterioration of firm performance and results, therefore, are mechanically driven by the performance of violators.

\footnotetext{
${ }^{27}$ The results are robust if I use the two-digit SIC industry indicator variables or 38 industry classification of SIC codes (Fama and French, 1997).

28 Another approach would be to use all quarters in estimations. This would increase the sample size but there would be many overlapping observations which may result in mechanical serial correlation in the dependent variables. In untabulated estimations, I include all obserrvations and use a firm and quarter clustering suggested in Peterson (2009), although the results remain robust, due to my concerns about serial correlation, the results are not reported in the paper.
} 
To alleviate sample selection problems, Roberts and Sufi (2009) use a "quasi-discontinuity" approach and exploit the discontinuity created in the violation quarter. The causal inferences from regression discontinuity approach are argued to be more credible than the typical natural experiment strategies such as difference-in-differences or instrumental variables methods (Lee and Lemieux (2009)). In my analysis, I use an approach which mimics the quasi-discontinuity approach in Roberts and Sufi (2009). ${ }^{29}$ An important issue is the difficulty in identifying the effect of violations separately from expected changes in outcomes related to differences in the underlying fundamentals of violators and non-violators. In order to address this issue, I use both the level and first-differences of the control variables before and after violations. This way, I hope to control for the differences of time-invariant and firm-level effects between non-violators and violators, and compare risk-shifting activities of violators relative to non-violators with a similar pre-violation pattern.

\section{Empirical results}

\section{A. The relation between risk and investment}

I start my analysis by examining borrowing firms' investment policy following violations. Table III shows the effect of covenant violations on firm investment. The first column of Table III shows a 2.1 percentage points decrease in total investment (sum of capital expenditures, acquisitions, and R\&D expenditures minus asset sales) following a covenant

29 Since we we do not observe the level of the covenant written in the contract, a standard regression-discontinuity design cannot be used. I use the level of covenant at the time of the violation and the change in the level of the covenant before and after the violation in my specifications to proxy for the unobserved levels of the covenant. 
violation. $^{30}$ This result is consistent with the findings of previous papers. In order to compare these results with previous research, I also investigate the impact of creditors on the subcomponents of investment. Consistent with Nini, Smith, and Sufi (2012), Column 2 and Column 3 of Table III presents evidence that capital and acquisition expenditure declines after covenant violations. Capital (cash acquisition) expenditure decreases by 0.9 (1.1) percentage points. ${ }^{31}$ Column 4 displays an insignificant effect of creditors on $R \& D$ expenditure. The change in $R \& D$ spending is insignificant, meaning that creditors have no effect on $R \& D$ spending. This is interesting since one would expect creditors to cut R\&D spending first due to the risky nature of these investments. The last column shows that there is no significant change in PPE sales following violations.

According to the real-options literature, the option to delay investment becomes more valuable when uncertainty about a project's cash flows and/or future funding shortfall is high. Managers can avoid potentially large losses by foregoing investment when the outcome is unfavorable. This manager/shareholder response to increased uncertainty is also consistent with creditors' actions. Chava and Roberts (2009) argue that some lenders "advise management to reduce investment expenditures" or put explicit investment restriction on new credit agreements following violations. When there is a risk-shifting problem; however, increased uncertainty may provide an opportunity for managers to invest in risky projects and increase equity value.

\footnotetext{
${ }^{30}$ Relative to an average annual investment rate of approximately $13.36 \%$ in nonviolation states, this estimate corresponds to a relative decrease in total investment of almost $15 \%$.

31 Relative to an average annual capital (cash acquisition) expenditure rate of approximately 5.25\% (3.49\%) in nonviolation states, this estimate corresponds to a relative decrease in capital (cash acquisition) expenditure of almost $18 \%(32 \%)$.
} 
Eisdorfer (2008) models and shows that in healthy firms, high uncertainty has a negative effect on investment. However, in financially constraint firms, this negative relationship becomes less negative or positive, consistent with the risk-shifting argument. ${ }^{32}$ Following Eisfdorfer (2008), I investigate the relation between investment and uncertainty to examine whether shareholder decisions are driven by first-best response (delaying investment) or agency conflicts (increase investment).

I add the variables Change in Risk and an interaction variable New Viol * Change in Risk to regression (1). Column 1 of Table IV shows how changes in risk affect firm investment. The coefficient of Change in Risk is -0.01 and significant at 1 percent level. It indicates that the relation between risk and investment is negative, consistent with prior literature (see, for example, Episcopos, 1995). Once firms violate a covenant, however, volatility-investment relation is different. The marginal effect of change in risk becomes significantly positive (0.03) at one percent level. ${ }^{33}$ This result is consistent with Eisdorfer (2008), who argues and shows that the effect of volatility on investment is less negative (or even positive) for firms with riskshifting problems. ${ }^{34}$ Columns 2 through 5 present the results for different measures of investment. The change in risk is positively related to change in capital expenditure and acquisition spending, similar to the results when total investment is used. The relation between

\footnotetext{
32 Please see Appendix A for a brief explanation of Eisdorfer's (2008) model.

${ }^{33}$ I also calculate the sum of the coefficients New Viol * Change in Risk and Change in Risk, which.is positive and significant at 12 percent level. Please see Table.A1 which reports correlations between these variables.

${ }^{34}$ It is also consistent with Mauer and Sarkar (2005) who argue that in firms with agency conflicts, high uncertainty encourages managers to invest in risky projects.
} 
volatility and R\&D expenditure is positive (although insignificant) following covenant violations.

To gauge the economic significance of these results, I calculate within-firm standard deviations and the effect of a one standard deviation change in Change in Risk on investment (unreported analysis). I next compare it to the effect of other right-hand side variables on investment. A one standard deviation increase in Change in Risk leads to a 5.57\% increase in the firm's investment. The marginal impact of change in risk on investment is greater than the impact of size $(-2.87 \%)$ and comparable to the effects of market-to-book (5.69\%) and operating cash flow (-4.09\%). This finding suggests that risk-shifting incentive has an economically meaningful effect on investment.

One concern is that the positive relation between investment and risk is driven by firms that decrease investment following violations. If decreased investment is associated with a decrease in risk (which suggests that creditors are able to reduce the firm risk with their actions), one would also observe a positive investment-volatility relationship. To investigate this possibility, I study the investment-risk relation for firms that have an increase (decrease) in risk following violations. I use a dummy variable, Increase in Risk, for firms with increased risk over the median firm in their industry (IRAR $>0$ ). The first column of Table V confirms that for firms which are not in violation of a covenant, increased risk is negatively associated with investment (-0.01, statistically significant). Moreover, decreased risk is associated with increased investment (the intercept is 0.034 , statistically significant). Once firms violate covenants, an increase in risk is positively associated with investment (the coefficient on the 
interaction variable Increase in Risk * New Viol is 0.028, statistically significant). Decrease in risk, however, is associated with increased investment (the sum of the intercept and the coefficient on New Financial Violation is positive, although not significant at a reasonable confidence level). Moreover, the sum of coefficients on Increase in Risk and Increase in Risk* New Viol is positive and significant at six percent level. ${ }^{35}$ This result shows that the negative relationship between investment and risk is reversed for firms once they violate a covenant. Moreover, the positive relation between investment and risk is not driven by firms that decrease investment following violations.

The second column in Table V separates the effect of initial versus subsequent violations on risk shifting. Models by Aghion and Bolton (1992) and Dewatripont and Tirole (1994) suggest that creditors have stronger influence over the borrowing firm after creditors initially obtain acceleration and termination rights. Consistent with these models, Roberts and Sufi (2009) show that significant changes in borrowing firms' financial policies occur after the initial violation as opposed to after subsequent violations. If creditors exert more influence over the firm after initial violations, these firms are less likely to engage in risk shifting. As a result, it is important to take into account how initial and subsequent violations affect risk-shifting behavior. The second column of Table $\mathrm{V}$ presents the results. First Time violation is defined to be a violation for a firm that violates a covenant for the first time. If the violation is not the first time

35 Please see Table.A1 which reports correlations between these variables. 
the firm violates a financial covenant, it is considered a Repeat violation. ${ }^{36}$ The estimates show that risk shifting is stronger for first-time violators (the coefficient on the interaction variable Increase in Risk * New viol * First Time is 0.026 and significant at two percent level). This finding provides evidence of risk shifting even in the presence of increased creditor control. ${ }^{37}$

The previous results provide evidence of risk shifting following violations. I next examine the risk-shifting behavior before the violation. This analysis is important for two reasons. First, although the quasi-discontinuity approach used in analyses mitigates the sample selection concerns, the evidence of risk shifting following violations may still be due to the different characteristics of violating firms and firms which have not violated a covenant. Second, Dewatripont and Tirole (1994) argue that control rights shift to creditors following "bad" managerial behavior such as risk shifting. To address these concerns, I examine the riskinvestment relation for one-time only violators before and after the violation. The first column of Table VI presents the relation between the change in risk and the change in total investment using all years before the violation. ${ }^{38}$ The coefficient is significantly negative $(-0.02)$. Even

\footnotetext{
${ }^{36}$ There are 1,071 first-time violators in the regression. Out of 1,071 firms, 129 of them violates a covenant second time and 8 of them violate a covenant third time. I re-do the analysis with these 129 firms that violate a covenant more than once. Risk shifting is stronger in their first time than their second and third time.

${ }^{37}$ An alternative explanation is that if subsequent violations signal that firms are near insolvency, the fiduciary duties of the directors are owed to creditors as well as shareholders. In this case, we would expect to see less risk shifting after subsequent violations. The results are mixed. Unlike the first-time violations, repeat violations have a much smaller effect on risk shifting, however, the estimate is not statistically significant at a reasonable confidence level. To further investigate whether the weak evidence on risk shifting is due to firms' financial health, I examine the financial situation of firms when they violate a covenant once and more than once. The untabulated results show that although repeat violations are related to lower $Z$-scores ( $Z$-score is 1.94 for median repeat violator versus 2.04 for median first time violators), repeat violators are not on the brink of becoming insolvent. These findings reassures that risk shifting occurs even when creditors have stronger control over borrowing firms.

${ }^{38}$ Suppose that the violation occurred at the end of 2000. The first column shows the investment-risk relation for all years before 2000 (i.e. 1997, 1998, 1999, and 2000). The second column shows the investment-risk relation in the year 2000. The last column shows the investment-risk relation in the year 2001.
} 
when I focus on the year before the violation, the relation between risk and investment is negative (-0.04, statistically significant). The third column shows the results for the firms after the violation. The coefficient becomes positive. These results indicate that the negative relation between risk and investment before the violation attenuates following the violation. This result reassures that the results are not driven by the differences in the two samples. Beyond ensuring the robustness of my inferences, these results indicate that violations are not the result of managerial risk shifting, at least for first-time violators. ${ }^{39}$

Next, I explore an alternative explanation for the positive investment-uncertainty relationship. In their theoretical paper, Boyle and Guthrie (2003) argue that the threat of future funding shortfalls reduces the value of a firm's timing options and leads to sub-optimal early investment. This argument also predicts a positive relation between investment and uncertainty. Since the risk of funding shortfall is more relevant for financially constrained firms, I investigate the risk-shifting incentives of these firms. I use the Whited and $\mathrm{Wu}$ (2006) index to measure financial constraints. A firm is financially constrained if it is in the upper third of the distribution following Chava and Roberts (2008). Table VII displays the results. Consistent with Boyle and Guthrie's (2003) predictions, the coefficient of Change in Risk * NewViol * Financially Constrained is 0.03 and statistically significant. However, the coefficient of Change in Risk* NewViol remains positive and statistically significant. This result shows that firms increase their

\footnotetext{
39 An alternative argument is that firms avoid taking risky investments sub-optimally to avoid the violation when they are close to a covenant violation. Once they violate a covenant, they start taking high-risk investment. This argument is not consistent with the extant literature on agency conflicts (see, for example, Jensen and Meckling, 1986). Table VI presents that the investment-risk relationship is negative for violators before the violation, consistent with managers following the first-best behavior. After the violation, the negative relation between investment and risk attenuates, consistent with risk shifting evidence.
} 
investment not only due to concerns about future financing capabilities, but also due to riskshifting incentives. ${ }^{40}$

In sum, this section provides evidence for risk-shifting behavior in firms which violate financial covenants. The next section explores further whether agency conflicts explain the change in investment-risk relation around covenant violations by looking at managerial incentives.

\section{B. Risk taking and managerial incentives}

The previous section shows heightened agency conflicts between shareholders and debtholders around violations. In this section, I examine the managerial incentives behind firms' risk-taking activities. I use three proxies that measure the extent of manager-shareholder interest alignment: 1) the sensitivity of CEO wealth to stock volatility (vega), 2) the sensitivity of CEO wealth to stock price (delta), and 3) managerial stock ownership.

A large literature has argued that equity-based compensation is awarded to managers to overcome managerial risk aversion and encourage risk-taking behavior (e.g., Smith and Stulz (1985), Guay (1999)). ${ }^{41}$ Empirical evidence shows that there is a positive association between vega and managerial risk taking (e.g. Hanlon, Rajgopal, and Shevlin (2004), Knopf, Nam, and Thornton (2002), Coles, Daniel and Naveen (2006), Brockman, Martion, and Unlu (2009)). This is because high stock return volatility increases the value of the executive stock options (Haugen

\footnotetext{
${ }^{40}$ Boyle and Guhtrie (2003)'s argument explains the positive investment-uncertainty relationship in a different way than the risk-shifting argument, both these arguments agree on the "sub-optimal" early investment.

${ }^{41}$ Another set of studies uses a utility-based framework and document that managerial risk-taking incentives are highly sensitive to certain compensation characteristics such as the option's moneyness and CEO's outside wealth (e.g. Brisley (2006)).
} 
and Senbet (1981), Smith and Stulz (1985)). High delta, however, is associated with greater managerial risk aversion (Knopf, Nam, and Thornton (2002), Chava and Purnanandam (2010)). This is due to the assumption that under-diversified and risk-averse managers prefer lower cash flow variance (e.g. Amihud and Lev (1981)). Equity ownership of managers is also shown to align manager-shareholder interests and mitigate managerial risk avoidance (e.g. Mehran (1995), Eisdorfer (2008)).

As the theory predicts, I find that the economic magnitude of the risk taking is higher for firms with high managerial risk-taking incentives. Table VIII presents the results for the regressions. I add the variables Increase in Risk (equals one if firm risk increase in the following year) and an interaction variable New Viol * Increase in Risk to the regression (4) to capture the possible risk-shifting behavior following violations. In order to show the effect of managerial incentives on risk-shifting behavior, I am primarily interested in the three-way interaction term, which captures the effect of managerial incentives on risk-shifting behavior. The two-way interaction variables are also included in the tests (not reported in the tables to save space).

The first column shows the effect of executive stock options on risk-shifting behavior. A firm is considered a high vega (delta) firm if the manager's vega (delta) is higher than the sample median. For firms whose managers' wealth is more sensitive to stock volatility, there is a more positive effect of increased risk on investment (coefficient is 0.03 and significant at five percent level). In contrast, high delta mitigates risk-shifting behavior (coefficient is -0.02 and significant at 10 percent level). The weak significance of this result may be due to mixed incentives 
provided by delta since delta measures both the incentive alignment effect and the risk-aversion effect (see Low (2009) for further discussion).

The second column shows the effect of managerial stock ownership on risk-shifting behavior. A firm is considered to be a high managerial ownership firm if the percentage of equity owned by the CEO is higher than the sample median. For firms with high CEO equity ownership, the effect of increased risk has a more positive effect on investment (coefficient is 0.02 and significant at 5 percent level).

\section{The change in risk following violations}

In this section, I examine the changes in firm risk following violations since shareholders with risk-shifting incentives and creditors have conflicting interests. Increased risk hurts debtholders and benefits shareholders by increasing the value of the put option imbedded in risky debt. Table IX shows the effect of covenant violations on firm risk using different measures. In each regression, I control for market-to-book, book leverage, size (log total assets), asset tangibility (PPE/lagged total assets), and operating income scaled by lagged assets as these variables may affect firms' risk. In all models, I take the natural logarithm of the dependent variable to control for outliers. Columns 1-6 show the change in risk using different firm risk

measures. All models except the one which uses systematic risk documents a significant increase in firm risk after covenant violations.

The first column reports the change in firm risk using industry adjusted risk adjustment ratio (IRAR). The coefficient of New Financial Covenant Violation is strongly negative and significant. Covenant violations are associated with a $5 \%$ increase in firm risk relative to the 
firm's industry median. Coefficient estimates on control variables are generally consistent with recent studies. For instance, high growth firms are more likely to have risky investments left in their investment opportunity set (Jensen and Meckling (1976)). Firms with larger cash holdings are mature firms which are less likely to take risky projects. The increase in risk goes up to $8 \%$ using the risk measures from the market model and $15 \%$ for the asset beta. ${ }^{42}$

The increase in risk should be interpreted with caution. One explanation for the increased risk is that the borrowing firm is moving to a riskier stage due to an economic shock. For instance, firms may face with a higher risk of losing employees, suppliers, clients, partners, and new deals. ${ }^{43}$ Figure I shows the pattern in equity volatility and earnings volatility. Although there is a jump in firm risk in the quarter following the violation, the increase in risk persists, lasting over two years following the violation. ${ }^{44}$ Another explanation is that shareholder actions drive the increase in risk. Managers, who are facing increased likelihood of losing control rights after violations, may follow riskier strategies. However, one may also argue that creditor actions dampen the increase in risk.

The increase in risk, together with the positive volatility-investment relation for firms violating covenants shows that shareholders are not giving up their control over the firm when creditors increase their influence. Creditors may be engaging in actions to reduce the riskshifting problem, but they cannot eliminate it.

\footnotetext{
${ }^{42}$ In the untabulated results, I add current asset volatility as a control variable. Parrino and Weisbach (2000) argue that firms with higher asset volatility are more likely to have fewer risky projects left in their investment opportunity set. I also add systematic volatility (volatility index, VIX) to further control for the trends in change in volatility. The results remain robust.

${ }^{43}$ For instance, Falato and Liang (2009) show that employment risk increases after a covenant violation.

${ }^{44}$ Moreover, the results are robust when I calculate the next year's volatility excluding the first quarter after the violation, suggesting that the results are not driven by announcement effect.
} 


\section{Robustness tests}

One concern is that the increase in risk following violations is due to the persistence in volatility (see Campbell and Taksler (2003)). Since volatility increases before and at the time of the violation, the increase in risk following violations may not be surprising. To control for the autocorrelation in volatility, I add to each model in Table IX the current volatility, lags and polynomials of volatility using the relevant risk measure. The results are qualitatively similar to those presented in Table IX and, as such, not tabulated. Thus, persistence in risk does not appear to be responsible for the increased risk following violations.

Another concern is the impact of measurement error in the volatility estimates. To address this concern, I estimate Table IV using analyst forecasts dispersion. The dispersion of analyst forecasts measures uncertainty in the firms' economic prospects (e.g. Diether, Malloy, and Scherbina (2002)). I use standard deviation of I/B/E/S earnings per share forecasts for the next fiscal year end, scaled by the absolute value of the mean estimate (Chava, Kumar, and Warga (2009)). Table $X$ presents the results, which are qualitatively similar. This finding reassures that the results are robust to the volatility measure choice and suggests that measurement error likely leads to conservative estimates of investment response to the increase in volatility. ${ }^{45}$

\footnotetext{
${ }^{45}$ The focus of this paper is not the effect of uncertainty on investment, but rather is the association between these two variables. Managers with risk shifting incentives may increase investment as a response to increased uncertainty. Investment decisions may also drive the degree of uncertainty. For example, if managers undertake risky investments, implied volatility may increase to reflect the uncertainty regarding future returns. These are both consistent with the risk-shifting argument. I investigate the effect of uncertainty on investment by using analyst
} 
Next, instead of using firm-specific ex-post volatility, I follow Eisdorfer (2008) and study the relationship between annual expected market volatility and capital expenditure. I calculate annual expected market volatility using a generalized autoregressive conditional heteroskedasticity $(\mathrm{GARCH})$ model, and employ a linear regression of capital expenditure on an interaction variable between expected volatility and a violation dummy. To manage the length of my study, I refer the reader to Eisdorfer (2008) for additional details. The untabulated results support the previous findings. The coefficient on volatility is -0.14 ( $\mathrm{p}$-value 0.08 ) for nonviolators and the coefficient on the interaction variable is 0.09 (p-value 0.12 ). ${ }^{46}$ One advantage of using firm-specific volatility, rather than expected market volatility is that the former captures uncertainty firms face arising from covenant violations. Firms which violate covenants may be more interested in the firm specific uncertainty. Moreover, I use industry adjusted risk adjustment ratio which takes into account industry-wide uncertainty.

An important issue may be that results are driven by the differences in firm characteristics between violator and non-violator firms. Since violations are not randomly assigned events, I use an empirical model to identify the effect of the violation as the difference between actual outcomes and the model (what would have happened at the absence of the violation). This way, I hope to mitigate the potential endogeneity problem by controlling for the level and changes in covenant control variables before and after the violation. As a robustness check, I re-estimate Table IV using two matching firm procedures. In the first procedure, for

forecast dispersion and expected market volatility. These tests reveal that uncertainty has a positive impact on investment for firms which violate a covenant.

${ }^{46}$ The table is available upon request. 
each violator firm, I choose a matching non-violator firm in the same year with the same 2-digit SIC, in same size decile and closest book-to-market. Table XI presents the estimation results for violators and corresponding matched firms. For non-violators, the association between change in risk and change in investment is significantly negative. The coefficient is -0.02 with a t-statistics of -2.5. This relation becomes positive for violator firms (the coefficient on the interaction variable is 0.02 , statistically significant). The results are similar when I use change in capital expenditure as the dependent variable. Second procedure is to employ a propensity score matching by matching the violator firm to a non-violator firm with similar pre-violation performance using many observable characteristics. In the first stage, I predict the probability of a firm violating a covenant (propensity score) using my full set of control variables. The violating firms are matched to non-violating firms based on the closest propensity score. The results are qualitatively similar to those presented in Table XI and, as such, not tabulated.

\section{Conclusion}

Recent studies suggest constraints on firms' behavior imposed by creditors following violations of financial covenants can benefit shareholders by curbing by managerial valuereducing overinvestment. The literature has not investigated, however, managers (who are acting on behalf of shareholders) engage in activities counter to creditor interests. This study fills in this gap by examining risk shifting behavior around violations.

A healthy firm will delay or forego the investment when uncertainty is high. Managers with risk-shifting incentives, however, increase investment when uncertainty is high. I show that there is negative association between volatility and investment before the violation. Once firms 
violate covenants; however, the negative relation between risk and investment reverses, consistent with risk shifting. This effect is more pronounced in firms where managers have incentives to take more risk. I find that risk shifting is more pronounced in firms with high CEO wealth sensitivity to stock volatility (vega) and with high managerial equity ownership. In contrast, managers whose wealth is more sensitive to stock prices are more risk averse. I also show that firm risk increases following violations and that the increase is persistent, lasting over two years following the violation.

While prior studies document that creditors increase control following covenant violations, I show that risk shifting occurs even in the presence of increased creditor control. This finding counters prior conclusions that shareholders and debtholders have common interests at violations. Creditor actions may help alleviate agency problems; however they do not fully prevent the problem.

A fruitful area for future empirical research would be to document the full set of actions shareholders can take to protect their control over the firm when covenants are violated. It would also be interesting to examine whether different features of covenants (e.g. covenant tightness, structure of debt, maturity of debt) alleviate shareholder-debtholder conflicts at violations. 


\section{Appendix A. Eisdorfer's (2008) Model}

In order to investigate the relation between investment and uncertainty to examine whether shareholder decisions are driven by first-best response (delaying investment) or agency conflicts (increase investment), I follow Eisdorfer (2008). Eisdorfer (2008) establish the baseline for the investment-risk relationship.

Eisdorfer (2008) constructs a three-date model where a firm holds an amount of cash (at $\mathrm{t}=0$ ) which is equal to the investment expenditure of a project the manager can undertake at $t=0$ or $t=1$. The value of the project is determined stochastically, income generated by the project is value of the project is proportional to the project's value. If the manager decides to postpone the investment, the cash earns a risk-free rate. The value of the firm at $\mathrm{t}=2$ depends on the firm's investment policy. If the manager takes the project at $t=0$, then the value of the firm at $t=2$ is equal the profits that are generated at $t=1$ and $t=2$ as well as the final value of the asset. If the firm undertakes the project at $t=1$ (not at $t=0$ ) then the value of the firm at $t=2$ is equal to the change in the amount of cash from $t=0$ to $t=1$ (remember cash earns a riskfree rate), the profit that is generated at $\mathrm{t}=2$ and the final value of the asset. If the firm does not undertake the project, then its value at $\mathrm{t}=2$ is simply equal to the future value of the cash holdings. Delaying the investment involves a trade-off between giving up the profit at $\mathrm{t}=1$ and gaining more information about the investment's value. Moreover, the firm has some debt that it has to pay as quickly as possible.

If the firm does not have large amount of debt, the manager prefer to postpone the investment decision to $\mathrm{t}=1$ since this enables the manager to compare the risk-free payoff from cash holdings with the expected payoff of the project at $t=2$. If the proceedings from cash holdings are higher than the expected payoff from investing, then the manager should not undertake the project, which creates convexity at the final payoff. The value of delaying the investment increases the degree of uncertainty about a project's cash 
flows. This implies that the expected payoff from waiting and gaining more information is higher than investing immediately, even at $\mathrm{t}=0$.

If the firm has large amount of debt, then the strategy may change. If the firm's debt is very high and if the manager postpones the investment decision to $t=1$, then the probability of receiving a positive equity pay-off becomes very small. In this case, the manager prefers to undertake the investment immediately (i.e. at $\mathrm{t}=0$ ) since the variance of the final payoff is greater than that when investment is delayed. If the increase in variance is large enough, this strategy increases the probability that equityholders receive a positive payoff at $\mathrm{t}=2$. In this case risk-shifting incentives outweigh the benefit of delaying the investment.

Eisdorfer (2008) solves his model by backward induction and uses a numerical solution to evaluate riskinvestment relation under different levels of bankruptcy risk. He shows that, when there is no bankruptcy risk, the investment threshold increases with asset volatility (a negative relation between investment and volatility). As bankruptcy risk increases, the negative relation is weakened, and even becomes positive when the default risk is high. I refer the reader to Eisdorfer (2008) for additional details. 


\section{Appendix B. Variable definitions for control variables}

All cash flow statement variables are first disaggregated into quarterly flows.

Total assets $=$ atq

Size $=\operatorname{lag}($ atq $)$

Market-to-book-ratio $=$ Market value $/$ Total assets where

Market value $=$ Market value of equity - book value of equity + Total assets

Market value of equity $=$ Price Close quarterly $*$ Common Shares Outstanding (prccq*cshoq)

Book value of equity $=$ Total assets - Total Liabilities (ltq) + Deferred Taxes and Investment Tax Credit (txditcq)

Total debt $=$ Debt in Current Liabilities (dltcq) + Total Long-Term Debt (dlttq)

Leverage ratio $=$ Total debt $/$ Total assets

Net worth scaled by assets ratio = Total Shareholders' Equity (seqq) $/$ Total assets

Current ratio $=$ Current Assets $($ actq) $/$ Current Liabilities (lctq)

Interest expense scaled by lagged assets $=$ Interest and Related Expense (xintq) / Lagged total assets

Capital expenditures quarterly = Capital expenditures (capxy) adjusted for fiscal quarter accumulation

Operating income scaled by lagged assets = Operating Income before Depreciation quarterly (oibdpq) / Lagged total assets

Research and Development expense scaled by assets $=$ R\&D Expense (xrdq) / Total assets

Research and Development expense scaled by sales= R\&D Expense (xrdq) / Sales (saleq)

Free cash flow $=$ Operating income before depreciation $(\mathrm{oibdpq})-$ interest expenses - income taxes (txtq)

- capital expenditures, scaled by total assets

PPE scaled by assets $=$ Tangible Assets $($ ppentq) $/$ Total assets

Total Investment $=\mathrm{R} \& D$ expenditure + Capital expenditure + Cash acquisition expenditure (aqcy) - Cash receipts from sale of property, plant, and equipment (SPPE ) / total assets

Whited-Wu Index $=-0.091 *$ Cash Flow $(\mathrm{dp}+\mathrm{ib})+0.062 *$ Dividend Dummy (equals one if the firm pays dividends $)+0.021 *$ Total Long Term Debt $-0.044 *$ Size $+0.102 *$ Industry Sales Growth $-0.035 *$ Sales Growth

Altman's Z-score = 1.2 (Working capital (nwc) /Total assets) +1.4 (Retained earnings (req) /Total assets) + 3.3 (Earnings before interest and taxes (nopiq+oibpq)/Total assets) + 0.6 (Market value of equity/ Total liabilities) +0.999 (Sales/Total assets) 


\section{Appendix C. Computation of asset volatility}

In Merton's model (1974), equity is viewed as a call option on the value of the firm's assets. Shareholders are the residual claimants to the firm's assets and are only subject to limited liability under bankruptcy. In this framework, the strike price of the call option is equal to the face value of the firm's liabilities and the option expires at time $T$ when the debt matures. At time $T$, shareholders will exercise their option and pay off debtholders if the value of the firm's assets is greater than the face value of its liabilities. If the value of the assets is not sufficient to fully repay the firm's debts, then the shareholders will let their call option expire. I estimate the value of equity:

$$
V_{E}=V_{A} N\left(d_{1}\right)-X e^{-r T} N\left(d_{2}\right)
$$

where $\mathrm{N}\left(\mathrm{d}_{1}\right)$ and $\mathrm{N}\left(\mathrm{d}_{2}\right)$ are the standard cumulative normal of $\mathrm{d}_{1}$ and $\mathrm{d}_{2} ; \mathrm{V}_{\mathrm{E}}$ is the current market value of equity; $\mathrm{V}_{\mathrm{A}}$ is the current market value of assets; $\mathrm{X}$ is the face value of debt maturing at time $\mathrm{T} ; \mathrm{r}$ is the continuously compounded risk-free rate;

$$
d_{1}=\frac{\left.\ln \left(V_{A} / X\right)+\left(r+\sigma_{A}^{2} / 2\right)\right) T}{\sigma_{A} T^{1 / 2}} \quad \text { (2) } \quad \text { and } \quad d_{2}=d_{1}-\sigma_{A} T^{1 / 2}
$$

where $\sigma_{\mathrm{A}}$ is the standard deviation of asset returns.

I estimate values of $\mathrm{V}_{\mathrm{A}}$ and $\sigma_{\mathrm{A}}$ by simultaneously solving the call option equation (equation (1)) and the optimal hedge equation, $\left[\sigma_{\mathrm{E}}=\mathrm{V}_{\mathrm{A}} \mathrm{N}\left(\mathrm{d}_{1}\right) \sigma_{\mathrm{A}} / \mathrm{V}_{\mathrm{E}}\right]$. $\mathrm{V}_{\mathrm{E}}$ is set equal to the total market value of equity based on the closing price at the end of the firm's fiscal year. $\sigma_{\mathrm{E}}$ is computed using daily return data from CRSP over the entire fiscal year. In order to have sufficient liquidity, I require at least 100 daily equity prices per calendar year. The face value of the firm's debt (strike price) is set equal to the current liabilities plus half the long-term debt, $\mathrm{T}$ equals one year, and $\mathrm{r}$ is the one-year Treasury bill rate from Ken French's website. The starting values are determined by setting $\mathrm{V}_{\mathrm{A}}$ equal to the book value of liabilities plus the market value of equity and $\sigma_{\mathrm{A}}=\sigma_{\mathrm{E}} \mathrm{V}_{\mathrm{E}} /\left(\mathrm{V}_{\mathrm{E}}+\mathrm{X}\right)$. The algorithm is repeated until convergence of asset volatility estimates from two consecutive iterations is obtained. In almost all cases, the process converges within five iterations. 


\section{Appendix D. Computation of managerial incentives (Delta and Vega)}

I calculate CEO wealth sensitivity to stock price (Delta) and CEO wealth sensitivity to equity volatility (Vega) using the methodology by Core and Guay $(1999,2002)$. I value CEO stock options using the Black-Scholes-Merton model (1973). The dollar values of Delta and Vega are:

$$
\begin{aligned}
& \text { Delta }=S e^{-\Phi \mathrm{T}} \mathrm{N}(Z) * n^{*} 0.01, \\
& \text { Vega }=\mathrm{Se}^{-\Phi \mathrm{T}} \mathrm{N}^{\prime}(Z) * \mathrm{Z}^{*} 0.01 * \mathrm{~T}^{1 / 2},
\end{aligned}
$$

where $S$ is the current stock price, $\Phi$ is the expected annual dividend rate over the life of the option, $\mathrm{n}$ is the number of options, $\mathrm{T}$ is time to maturity for options, $\mathrm{N}($.$) is the cumulative probability$ distribution for the normal distribution function, $\mathrm{N}^{\prime}($.$) is the normal density function, \sigma_{\mathrm{e}}$ is the annualized stock return volatility, $K$ is the strike price of options, and $Z=\ln (S / K)+\left(r-\Phi+\left(\sigma_{e}^{2} / 2\right)\right) T / \sigma_{e} T^{1 / 2}$.

I obtained the data on executive's option portfolio from Execucomp. Execucomp provides sufficient information on new grants. However, I need to estimate average strike price using current realizable value and time to maturity for of exercisable and unexercisable options. The average exercise price is: year-end price - (realizable value/number of options). Time to maturity of unexercisable options is equal to one year less than time-to-maturity of most recent year's grant (or nine years if no new grant was made). Time-to maturity of exercisable options equal to three years less than time-to-maturity of unexercisable options (or six years if no new grant was made). ${ }^{47}$ The other inputs (stock price, expected stock-return volatility, and expected dividend yield) are readily available.

After calculating dollar value of these different kinds of options (new grants, unexercisable options and exercisable options), I add their values up. This gives me the total dollar values of Delta and Vega.

\footnotetext{
${ }^{47}$ This is due to the assumption that unexercisable options have a time-to-maturity that is three years greater than that of the exercisable options.
} 
Table A1

\section{Correlation Matrix}

This table reports Pearson rank correlations between key variables used in Table IV and V. A new covenant violation is a financial covenant violation by a firm that has not violated a covenant for the previous four quarters. Change in Risk is equal to the natural logarithm of 1+IRAR. Increase in Risk is 1 if next year's risk is higher than current year's risk, adjusted by 2-digit SIC industry median (i.e. IRAR>0), and 0 otherwise.

\begin{tabular}{lccccc} 
& $\begin{array}{c}\text { New Financial } \\
\text { Covenant } \\
\text { Violation }\end{array}$ & $\begin{array}{c}\text { Change in } \\
\text { Risk* } \\
\text { New Viol }\end{array}$ & $\begin{array}{c}\text { Change in } \\
\text { Risk }\end{array}$ & $\begin{array}{c}\text { Increase in } \\
\text { Risk }\end{array}$ & $\begin{array}{c}\text { Increase in } \\
\text { Risk* New } \\
\text { Viol }\end{array}$ \\
\hline Mean & 0.030 & 0.002 & 0.071 & 0.548 & 0.015 \\
St. Dev. & 0.171 & 0.076 & 0.727 & 0.498 & 0.122 \\
$\mathrm{~N}$ & 59,777 & 44,679 & 44,679 & 44,682 & 44,682 \\
\hline & & & & & \\
\hline New Financial Covenant Violation & \multirow{2}{*}{1.000} & 0.160 & 0.001 & 0.003 & 0.741 \\
Change in Risk* New Viol & & 1.000 & 0.102 & 0.114 & 0.584 \\
Change in Risk & & & 1.000 & 0.355 & 0.049 \\
Increase in Risk & & & & 1.000 & 0.112 \\
Increase in Risk* New Viol & & & & & \\
\hline
\end{tabular}




\section{References}

Aghion, Philippe, and Patrick Bolton, 1992, An incomplete contracts approach to financial contracting, Review of Economic Studies 59, 473-494.

Aggarwal Rajesh and Andrew Samwick, 2003, Why do managers diversify their firms? Agency reconsidered, Journal of Finance 58, 71-118.

Amihud, Yakov, and Baruch Lev, 1981, Risk reduction as a managerial motive for conglomerate mergers, Bell Journal of Economics 12, 605-617.

Andrade, Gregor, and Steven N. Kaplan, 1998, How costly is financial (not economic) distress? Evidence from highly leveraged transactions that became distressed, Journal of Finance 53, 1443-1493.

Barclay, Michael J., and Clifford W. Smith, 1995a, The maturity structure of corporate debt, Journal of Finance 50, 609-631.

Baum, Christopher F., Mustafa Caglayan, and Oleksandr Talavera, 2008, Uncertainty determinants of firm investment, Economics Letters 98, 282-287.

Beneish, Messod D., and Eric Press, 1993, "Costs of technical violation of accounting- based debt covenants", The Accounting Review 68, 233-57.

Beneish, Messod and Eric Press, 1995, The resolution of technical default, The Accounting Review 70: 337-353.

Billett, Matthew, Tao-Hsien D. King, and David C. Mauer, 2007, Growth opportunities and the choice of leverage, debt maturity, and covenants, The Journal of Finance, 62(2), 697-730.

Black, Fisher, and Myron Scholes, 1973, The pricing of options and corporate liabilities, Journal of Political Economy 81, 637-659.

Bradley, Michael, and Michael Roberts, 2004, The structure and pricing of corporate debt covenants, Working paper.

Boyle, Glenn W., and Graeme A. Guthrie, 2003, Investment, uncertainty and liquidity, Journal of Finance $58,2143-2166$.

Brisley, Neil, 2006, Executive stock options: Early exercise provisions and risk-taking incentives, Journal of Finance 61, 2487-2509.

Brockman, Paul, Xiumin Martin, and Emre Unlu, 2009, Executive compensation and the maturity structure of corporate debt, Journal of Finance, forthcoming.

Bulan, Laarni T., 2005, Real options, irreversible investment and firm uncertainty: New evidence 
from U.S. firms, Review of Financial Economics 14, 255-279.

Caballero, Ricardo J., and Robert S. Pindyck, 1996, Uncertainty, investment and industry evolution, International Economic Review 37, 641-662.

Campbell, John Y., and Glen B. Taksler, 2003, Equity volatility and corporate bond yields, Journal of Finance 58, 2321-2449.

Chava, Sundheer, and Michael Roberts, 2008, How does financing impact investment? The role of debt covenants, Journal of Finance 63:2085-2121.

Chava, Sundheer, and Praveen Kumar, and Arthur Warga, 2009, Managerial agency and bond covenants, Review of Financial Studies, forthcoming.

Chen, Kevin C. W. and K. C. John Wei, 1993, Creditors' decisions to waive violations of accountingbased debt covenants, The Accounting Review 68: 218-232.

Cohen, Randolph B., Brian J. Hall, and Luis M. Viceira, 2000, Do executive stock options encourage risktaking?, Working paper, Harvard Business School.

Coles, Jeffrey L., Naveen D. Daniel, and Lalitha Naveen, 2006, Managerial incentives and risk-taking, Journal of Financial Economics 79, 431-468.

Core, John, and Wayne R. Guay, 2002, Estimating the value of employee stock option portfolios and their sensitivities to price and volatility, Journal of Accounting Research 40, 613-630.

Crosbie Peter, and Jeff Bohn, 2003, Modeling Default Risk, available from www . defaultrisk . com, Moody's KMV.

Daniel, Naveen D., J. Spencer Martin, and Lalitha Naveen, 2004, The hidden cost of managerial incentives: Evidence from the bond and stock markets, Working paper.

Datta, Sudip, Mai Iskandar-Datta, and Kartik Raman, 2001, Executive compensation and corporate acquisition decisions, Journal of Finance 56, 2299-2336.

De Jong, Abe, and Ronald Van Dijk, 2001, Determinants of leverage and agency problems, Working paper, Tilburg University.

Demiroglu, Cem, and Christopher James, 2010, The information content of bank loan covenants, Review of Financial Studies 23, 3700-3737.

Dewatripont, Mathias, and Jean Tirole, 1994, A theory of debt and equity: diversity of securities and manager-shareholder congruence, Quarterly Journal of Economics 109: 1027-1054. 
Dichev, Ilia D., and Douglas J. Skinner, 2002, Large sample evidence on the debt covenant hypothesis, Journal of Accounting Research 40: 1091 - 1123.

Diether Karl, Christopher J. Malloy, and Anna Scherbina,2002, Differences of Opinion and the Cross Section of Stock Returns, Journal of Finance 57, 2113-2141.

Dixit, Avinash K., and Robert S. Pindyck, 1994. Investment Under Uncertainty (Princeton, N.J., Princeton University Press).

Eisdorfer, Assaf, 2008, Empirical evidence of risk shifting in financially distressed firms", Journal of Finance, 63(2), 609-637(29).

Episcopos, Athanasios, 1995, Evidence on the relationship between uncertainty and irreversible investment, Quarterly Review of Economics and Finance 35, 41-52.

Esty, Benjamin C., 1997, Organizational form and risk taking in the savings and loan industry, Journal of Financial Economics 44, 25-55

Falato, Antonio, and Nellie Liang, 2012, Do creditor rights increase employment risk? Evidence from debt covenants, Working paper, Federal Reserve Board

Fang, Ming, and Rui Zhong, 2004, Default risk, firm's characteristics, and risk shifting, Working paper, Yale ICF (04-21).

Fargher Neil L., Michael S. Wilkins, and Lori M. Holder-Webb, 2001, Initial technical violations of debt covenants and changes in firm risk, Journal of Business and Accounting 28, 465-480.

Galai, Dan, and Ronald Masulis, 1976, The option pricing model and the risk factor of stock, Journal of Financial Economics 3, 53-81.

Ghosal, Vivek, and Prakash Loungani, 1996, Product market competition and the impact of price uncertainty on investment: Some evidence from US manufacturing industries, Journal of Industrial Economics 44, 217-228.

Gorton, Gary, and James Kahn, 2000, The design of bank loan contracts, Review of Financial Studies 13(2), 331-364.

Goyal, Amit, and Pedro Santa-Clara, “Idiosyncratic Risk Matters!,” June 2003, Journal of Finance 58(3), 975-1007.

Graham, John R., and Campbell R. Harvey, 2001, The theory and practice of corporate finance: Evidence from the field, Journal of Financial Economics 60, 187-243.

Gopalakrishnan, V., and Mohinder Parkash, 1995, Borrower and lender perceptions of accounting information in corporate lending agreements, Accounting Horizons 9, 13-26. 
Guay, Wayne R., 1999, The sensitivity of CEO wealth to equity risk: An analysis of the magnitude and determinants, Journal of Financial Economics 53, 43-71.

Hanlon, Michelle, Shivaram Rajgopal, and Terry J. Shevlin, 2004, Large sample evidence on the relation between stock option compensation and risk taking, Working paper, University of Michigan and University of Washington.

Hart, Oliver, 1995. Firm, Contracts and Financial Structure, (Clarendon Press, Oxford).

Haugen, Robert A., and Lemma W. Senbet,1981, Resolving the agency problems of external capital through options, Journal of Finance, Vol. 36 No.3, pp.629-47.

Hjortshøj, Toke, and Chenyang Wei, 2009, Debt Governance and Risk Taking, Working paper .

Hillegeist, Stephen A., Elizabeth K. Keating, Donald P. Cram, and Kyle G. Lundstedt, 2004, Assessing the probability of bankruptcy, Review of Accounting Studies 9, 5-34.

Jensen, Michael C., and William H. Meckling, 1976, Theory of the Firm: managerial behavior, agency costs, and ownership structure, Journal of Financial Economics 3, 305-360.

Johnson, Shane A., 2003, Debt maturity and the effects of growth opportunities and liquidity risk on leverage, Review of Financial Studies 16, 209-236.

Knopf, John D., Jouahn Nam, and John H. Thornton Jr., 2002, The volatility and price sensitivities of managerial stock option portfolios and corporate hedging, Journal of Finance 57, 80-812.

Laeven, Luc, and Ross Levine, 2009, Bank governance, regulation, and risk-taking, Journal of Financial Economics, Vol. 93(2), 259-275.

Larsen, Peter T., 2007, Default risk, debt maturity and levered equity's risk shifting incentives, CAF, Centre for Analytical Finance

Leahy, John V., and Toni M. Whited, 1996, The effect of uncertainty on investment: Some stylized facts, Journal of Money, Credit, and Banking 28, 64-83.

Lee, David S., and Thomas Lemieux, 2010, Regression discontinuity designs in economics, Journal of. Economic Literature, 48, 287-355.

Low, Angie, 2009, Managerial risk taking behavior and executive compensation, Journal of Financial Economics 92, 470-490.

Malitz, Ileen, 1986, On financial contracting: The determinants of bond covenants, Financial Management 15, 18-25.

Mauer, David C., and Sudipto Sarkar, Real options, agency conflicts, and optimal capital 
Structure, Journal of Banking and Finance, 29, 1405-1428.

McDonald, Robert, and Daniel Siegel, 1986, The value of waiting to invest, Quarterly Journal of Economics 101, 707-727.

Mehran, Hamid, 1995, Executive compensation structure, ownership, and firm performance, Journal of Financial Economics 38, 163-184.

Merton, Robert C., 1974, On the pricing of corporate debt: The risk structure of interest rates, Journal of Finance 29, 449-470.

Minton, Bernadette A., and Catherine Schrand, 1999, The impact of cash flow volatility on discretionary investment and the costs of debt and equity financing, Journal of Financial Economics 54, 423-460.

Nini, Greg, David C. Smith, and Amir Sufi, 2012, Creditor control rights, corporate governance, and firm value, The Review of Financial Studies 25, 1713-1761.

Nini, Greg, David C. Smith, and Amir Sufi, 2009, Creditor control rights and firm investment policy, Journal of Financial Economics 92: 400-420.

Papanikolaou, Dimitris, and Vasia, Panousi, 2012, Investment, idiosyncratic risk, and ownership, Journal of Finance 67, 1113-1148.

Parrino, Robert, and Michael S. Weisbach, 1999, Measuring investment distortions arising from stockholder bondholder conflicts, Journal of Financial Economics 53, 3-42.

Pindyck, Robert S., 1988, Irreversible investment, capacity choice and the value of the firm, American Economic Review 78, 969-985.

Pindyck, Robert S., and Andres Solimano, 1993, Economic instability and aggregate investment, NBER Macroeconomics Annual 8, 259-303.

Rajgopal, Shivaram, and Terry Shevlin, 2002, Empirical evidence on the relation between stock option compensation and risk taking, Journal of Accounting and Economics 33, 145-171.

Roberts, Michael, and Amir Sufi, 2009, Control rights and capital structure: An empirical investigation, Journal of Finance 64, 1657-1695.

Saunders, Anthony, Elizabeth Strock, and Nickolaos G. Travlos, 1990, Ownership structure, deregulation, and bank risk taking, Journal of Finance 45, 643-654.

Smith, Clifford W., René M. Stulz, R.M., 1985, The determinants of firms' hedging policies, Journal of Financial and Quantitative Analysis 20, 391-405. 
Smith, Clifford Jr., and Jerold B. Warner, 1979, On financial contracting: an analysis of bond covenants, Journal of Financial Economics 7, 117-161.

Stein, Luke C.D., and Elizabeth C. Stone, 2010, The Effect of Uncertainty on Investment: Evidence from Options, Working paper, Stanford University.

Trigeorgis, Lenos, 1996. Real Options (Cambridge, M.A., MIT Press).

Tirole, Jean, 2006, The Theory of Corporate Finance (Princeton University Press, Princeton).

Vassalou, Maria, and Yuhang H. Xing, 2004, Default risk in equity returns, Journal of Finance 59, 831868.

Whited, Toni, and Guojun Wu, 2006, Financial constraints risk, Review of Financial Studies 19, 531559.

Wilkins, Michael S., 1997, Technical default, auditors' decisions and future financial distress, Accounting Horizons 11, 40-48.

Williams, Joseph T., 1987, Perquisites, risk, and capital structure, Journal of Finance 42, 29-48. 
Table I

Financial Covenant Violations (1996-2007)

This table presents the percentage of firms that report a financial covenant violation during the fiscal year from 1996 to 2007. A new covenant violation is a financial covenant violation by a firm that has not violated a covenant for the previous four quarters. The sample includes 9,915 firms.

\begin{tabular}{cccccc}
\hline & \multicolumn{2}{c}{ Covenant Violation } & & \multicolumn{2}{c}{ New Covenant Violation } \\
\cline { 2 - 3 } \cline { 5 - 6 } Year & $\begin{array}{c}\text { Violation } \\
\text { Incidence }\end{array}$ & $\begin{array}{c}\text { Percentage } \\
\text { of Sample }\end{array}$ & & $\begin{array}{c}\text { Violation } \\
\text { Incidence }\end{array}$ & $\begin{array}{c}\text { Percentage } \\
\text { of Sample }\end{array}$ \\
\hline 1996 & 6,240 & $10.50 \%$ & & 0 & $0.00 \%$ \\
1997 & 6,550 & $11.74 \%$ & & 315 & $5.00 \%$ \\
1998 & 6,409 & $14.60 \%$ & & 480 & $7.59 \%$ \\
1999 & 6,366 & $15.60 \%$ & & 483 & $8.01 \%$ \\
2000 & 6,267 & $16.26 \%$ & & 502 & $5.64 \%$ \\
2001 & 5,676 & $11.64 \%$ & & 511 & $5.70 \%$ \\
2002 & 5,121 & $12.18 \%$ & & 399 & $6.65 \%$ \\
2003 & 4,784 & $16.07 \%$ & & 318 & $5.70 \%$ \\
2004 & 4,613 & $12.18 \%$ & & 263 & $5.64 \%$ \\
2005 & 4,554 & $11.64 \%$ & & 257 & $5.78 \%$ \\
2006 & 4,445 & $11.27 \%$ & & 257 & $4.99 \%$ \\
2007 & 4,325 & $10.68 \%$ & & 216 & $7.59 \%$ \\
Total & 65,350 & $14.02 \%$ & & 4,001 & $6.12 \%$ \\
\hline
\end{tabular}


Table II

Summary Statistics

This table presents summary statistics of variables for the sample from 1996 to 2007. A new violator is a firm that has not violated a covenant for the previous four quarters. Panel A and Panel B display the descriptive statistics for covenant control variables and other firm characteristics for violators and non-violators. Panel $\mathrm{C}$ presents summary statistics for key variables that are used to measure firm risk. Panel D presents the summary statistics for managerial incentives. The risk adjustment ratio $(R A R)$ is the ratio between the current and next year's asset risk. The industry adjusted risk adjustment ratio (IRAR) is the difference between the firm's RAR and median RAR of the firms in the same 2-digit SIC code in the same year. Vega is the dollar change in CEO stock holdings for a $1 \%$ change in stock return volatility. Delta is the dollar change in CEO stock holdings for a $1 \%$ change in stock price. See Appendix B for variable definitions.

\begin{tabular}{|c|c|c|c|c|c|c|c|c|c|c|c|c|}
\hline & \multicolumn{12}{|c|}{ Panel A. Covenant Control Variables } \\
\hline & \multicolumn{6}{|c|}{ New Violators } & \multicolumn{6}{|c|}{ Non-Violators } \\
\hline & $\mathrm{N}$ & 10th & 25 th & 50 th & 75 th & 90th & $\mathrm{N}$ & 10th & 25 th & 50 th & 75 th & 90th \\
\hline Market-to-Book & 3,810 & 0.77 & 0.92 & 1.18 & 1.64 & 2.52 & 180,443 & 0.84 & 1.05 & 1.44 & 2.29 & 3.88 \\
\hline Leverage Ratio & 3,897 & 0.03 & 0.15 & 0.30 & 0.47 & 0.64 & 187,014 & 0.00 & 0.02 & 0.19 & 0.37 & 0.55 \\
\hline Current Ratio & 3,898 & 0.63 & 1.01 & 1.49 & 2.30 & 3.45 & 188,041 & 0.79 & 1.23 & 1.96 & 3.27 & 5.84 \\
\hline Net Worth scaled by assets & 4,001 & 0.06 & 0.24 & 0.40 & 0.57 & 0.72 & 193,031 & 0.14 & 0.31 & 0.50 & 0.71 & 0.84 \\
\hline Interest expense / lag(assets) & 3,391 & 0.00 & 0.00 & 0.01 & 0.01 & 0.02 & 158,547 & 0.00 & 0.00 & 0.00 & 0.01 & 0.01 \\
\hline Operating income / lag(assets) & 3,637 & -0.07 & -0.02 & 0.01 & 0.03 & 0.04 & 177,834 & -0.06 & 0.00 & 0.03 & 0.04 & 0.07 \\
\hline
\end{tabular}

Size (Log_atq)

PPE/assets

Total Debt

Free Cash Flow/Assets

Market Value Equity/Assets

Sales/Assets

Panel B. Other Firm Characteristics

\begin{tabular}{rrrrrrrrrrrrr}
\hline \multicolumn{1}{c}{ New Violators } \\
\hline \multicolumn{1}{c}{ N } & 10th & 25th & 50th & 75th & 90th & N & 10th & 25th & 50 th & 75th & 90 th \\
\hline 4,001 & 2.74 & 3.58 & 4.75 & 6.04 & 7.25 & 193,044 & 2.66 & 3.68 & 5.10 & 6.65 & 8.03 \\
3,996 & 0.05 & 0.10 & 0.21 & 0.41 & 0.65 & 192,525 & 0.03 & 0.08 & 0.19 & 0.39 & 0.65 \\
3,897 & 1.16 & 5.55 & 24.91 & 139.70 & 568 & 187,014 & 0.00 & 1.11 & 16.78 & 198.05 & 916.86 \\
3,522 & -0.09 & -0.02 & 0.00 & 0.02 & 0.03 & 173,729 & -0.08 & -0.01 & 0.02 & 0.03 & 0.05 \\
4,001 & 0.12 & 0.27 & 0.55 & 1.06 & 1.92 & 194,408 & 0.22 & 0.47 & 0.94 & 1.82 & 3.41 \\
4,001 & 0.08 & 0.16 & 0.27 & 0.40 & 0.58 & 193,044 & 0.55 & 0.13 & 0.24 & 0.38 & 0.62
\end{tabular}


Panel B. Other Firm Characteristics (cont.)

\begin{tabular}{|c|c|c|c|c|c|c|c|c|c|c|c|c|}
\hline & \multicolumn{5}{|c|}{ New Violators } & \multicolumn{7}{|c|}{ Non-Violators } \\
\hline & $\mathrm{N}$ & 10th & 25 th & 50th & 75th & 90th & $\mathrm{N}$ & 10th & 25 th & 50th & 75 th & 90th \\
\hline Market Value & 3,810 & 19.61 & 45.53 & 138.42 & 481.3 & 1661.6 & 180,443 & 21.36 & 59.44 & 239.48 & $1,104.6$ & $4,483.2$ \\
\hline RD/assets & 1,862 & 0.00 & 0.00 & 0.01 & 0.04 & 0.07 & 95,473 & 0.00 & 0.00 & 0.02 & 0.04 & 0.08 \\
\hline RD/sales & 1,858 & 0.00 & 0.00 & 0.06 & 0.16 & 0.32 & 93,178 & 0.00 & 0.01 & 0.08 & 0.21 & 0.78 \\
\hline Zscore & 3,490 & -1.27 & 0.77 & 1.95 & 3.15 & 5.01 & 168,774 & -0.74 & 1.31 & 2.94 & 5.33 & 10.31 \\
\hline \multirow[t]{4}{*}{ Credit Rating } & 740 & $\mathrm{BBB}$ & $\mathrm{BB}$ & BB- & $\mathrm{B}$ & B- & 44,480 & $\mathrm{~A}$ & $\mathrm{BB}+$ & $\mathrm{BB}+$ & BB- & B \\
\hline & \multicolumn{12}{|c|}{ Panel C. Firm Risk Variables } \\
\hline & \multicolumn{6}{|c|}{ New Violators } & \multicolumn{6}{|c|}{ Non-Violators } \\
\hline & $\mathrm{N}$ & 10th & 25 th & 50 th & 75 th & 90th & $\mathrm{N}$ & 10th & 25 th & 50th & 75 th & 90th \\
\hline Total Equity Risk & 1,600 & 0.37 & 0.51 & 0.72 & 0.99 & 1.34 & 43,172 & 0.27 & 0.37 & 0.55 & 0.83 & 1.17 \\
\hline Unsystematic Risk & 1,600 & 0.35 & 0.49 & 0.70 & 0.96 & 1.31 & 43,172 & 0.25 & 0.34 & 0.52 & 0.79 & 1.14 \\
\hline Systematic Risk & 1,600 & 0.05 & 0.08 & 0.15 & 0.23 & 0.34 & 43,172 & 0.05 & 0.09 & 0.14 & 0.21 & 0.31 \\
\hline Equity Beta & 1,600 & 0.17 & 0.53 & 1.01 & 1.59 & 2.19 & 43,172 & 0.25 & 0.60 & 1.08 & 1.64 & 2.26 \\
\hline Asset Beta & 1,577 & 0.06 & 0.21 & 0.54 & 1.07 & 1.70 & 42,626 & 0.13 & 0.38 & 0.80 & 1.39 & 2.03 \\
\hline Asset Volatility & 1,537 & 0.16 & 0.26 & 0.39 & 0.61 & 0.91 & 41,018 & 0.17 & 0.25 & 0.39 & 0.62 & 0.91 \\
\hline RAR & 1,207 & 0.61 & 0.79 & 1.03 & 1.34 & 1.79 & 33,748 & 0.63 & 0.77 & 0.95 & 1.18 & 1.47 \\
\hline IRAR & 1,207 & -0.32 & -0.16 & 0.04 & 0.36 & 0.79 & 33,748 & -0.31 & -0.16 & 0.00 & 0.20 & 0.47 \\
\hline
\end{tabular}

Panel D. Managerial Incentives

\begin{tabular}{|c|c|c|c|c|c|c|c|c|c|c|c|c|}
\hline & \multicolumn{12}{|c|}{ Panel D. Managerial Incentives } \\
\hline Vega & 307 & 25.237 & $3,442.68$ & 22,279 & 99,164 & 422,857 & 14,735 & $1,497.2$ & 13,150 & 56,483 & 214,849 & 914,506 \\
\hline
\end{tabular}




\section{Table III}

\section{The Effect of Financial Covenant Violations on Firms' Investment}

This table presents first difference estimates of the marginal effect of covenant violation on firm investment from the quarter of the violation to one year after the violation. Covenant control variables include operating cash flow scaled by lagged assets, the leverage ratio, interest expense scaled by lagged assets, net worth scaled by assets, the current ratio, and the market-to-book ratio. All specifications include industry, year fixed effects, lagged first difference covenant control variables, first difference covenant control variables and higher order covenant control variables. First difference covenant control variables are differences from the quarter of the violation to one year after the violation. Lagged first difference covenant control variables are differences from one year ago to the present quarter of each of these variables. Higher order covenant control variables are covenant control variables raised to the second and third power. The sample is limited to firms-quarter observations in the fourth quarter of each year. Standard errors are clustered by firm. ***, and $* * *$ indicate significance at the $10 \%, 5 \%$, and $1 \%$ levels, respectively. See Appendix B for variable definitions.

(Investment Measure/ Lagged Assets) $_{t+4}$ - (Investment Measure/ Lagged Assets) $t$

\begin{tabular}{|c|c|c|c|c|c|}
\hline & $\begin{array}{c}\text { Total } \\
\text { Investment }\end{array}$ & $\begin{array}{c}\text { Capital } \\
\text { Expenditure }\end{array}$ & $\begin{array}{l}\text { Acquisition } \\
\text { Expenditure }\end{array}$ & $\begin{array}{c}\text { R\&D } \\
\text { Expenditure }\end{array}$ & $\begin{array}{l}\text { Sale of } \\
\text { PPE }\end{array}$ \\
\hline \multirow[t]{2}{*}{ New Financial Covenant Violation } & $-0.021 * * *$ & $-0.009 * * *$ & $-0.011 * * *$ & -0.002 & 0.000 \\
\hline & 0.005 & 0.002 & 0.004 & 0.002 & 0.001 \\
\hline \multirow{2}{*}{ Market-to-Book ratio } & 0.003 & 0.000 & $0.002 * * *$ & 0.001 & 0.000 \\
\hline & 0.002 & 0.000 & 0.000 & 0.002 & 0.001 \\
\hline \multirow[t]{2}{*}{ Current Ratio } & $0.004 * * *$ & $0.001 * * *$ & $0.001 * * *$ & $0.001 * * *$ & 0.000 \\
\hline & 0.001 & 0.000 & 0.000 & 0.000 & 0.000 \\
\hline \multirow[t]{2}{*}{ Net worth/assets } & 0.011 & $-0.007 * * *$ & $-0.007 * *$ & $0.020 * *$ & $-0.006^{*}$ \\
\hline & 0.013 & 0.003 & 0.003 & 0.008 & 0.008 \\
\hline \multirow[t]{2}{*}{ Interest expense/lagged assets } & $-0.643 *$ & 0.099 & $-0.344 * * *$ & $-0.405 *$ & -0.086 \\
\hline & 0.339 & 0.144 & 0.133 & 0.218 & 0.102 \\
\hline \multirow[t]{2}{*}{ Leverage Ratio } & $-0.066 * * *$ & $-0.013 * * *$ & $-0.032 * * *$ & 0.005 & 0.007 \\
\hline & 0.017 & 0.005 & 0.007 & 0.013 & 0.010 \\
\hline \multirow[t]{2}{*}{ Operating cash flow/lagged assets } & $-0.199 * * *$ & 0.009 & 0.002 & $-0.207 * * *$ & $-0.015 *$ \\
\hline & 0.054 & 0.012 & 0.009 & 0.043 & 0.008 \\
\hline Additional Control Variables & Yes & Yes & Yes & Yes & Yes \\
\hline $\mathrm{N}$ & 22,817 & 23,949 & 24,329 & 25,549 & 25,549 \\
\hline $\mathrm{R}^{2}$ & 0.075 & 0.047 & 0.044 & 0.053 & 0.012 \\
\hline
\end{tabular}




\section{Table IV}

The relation between change in investment and change in risk

This table presents the relation between risk and investment following covenant violation in the year following the violation. Change in Risk is equal to the natural logarithm of $1+\mathrm{IRAR}$. In each specification, change in investment is equal to the difference of investment measure scaled by lagged assets from the quarter of the violation to one year after the violation. All specifications include industry, year fixed effects, lagged first difference covenant control variables, first difference covenant control variables and higher order covenant control variables. Additional control variables are described in Table III. The sample is limited to firms-quarter observations in the fourth quarter of each year. Standard errors are clustered by firm. *,**, and *** indicate significance at the $10 \%, 5 \%$, and $1 \%$ levels, respectively.

\begin{tabular}{|c|c|c|c|c|c|}
\hline & $\begin{array}{c}\text { Change } \\
\text { in Total } \\
\text { Investment }\end{array}$ & $\begin{array}{c}\text { Change } \\
\text { in Capital } \\
\text { Expenditure }\end{array}$ & $\begin{array}{c}\text { Change } \\
\text { in Cash } \\
\text { Acquisition }\end{array}$ & $\begin{array}{c}\text { Change } \\
\text { in R\&D } \\
\text { Expenditure }\end{array}$ & $\begin{array}{c}\text { Sale of Plant, } \\
\text { Property and } \\
\text { Equipment }\end{array}$ \\
\hline \multirow[t]{2}{*}{ New Financial Covenant Violation } & $-0.019 * * *$ & $-0.012 * * *$ & -0.005 & -0.001 & 0.000 \\
\hline & 0.005 & 0.002 & 0.005 & 0.002 & 0.001 \\
\hline \multirow[t]{2}{*}{ Change in Risk } & $-0.011 * * *$ & $-0.003 * *$ & $-0.010 * * *$ & 0.003 & $0.002 * *$ \\
\hline & 0.004 & 0.001 & 0.002 & 0.002 & 0.001 \\
\hline \multirow[t]{2}{*}{ Change in Risk* New Viol } & $0.031 * * *$ & $0.007 *$ & $0.019 * *$ & 0.004 & -0.001 \\
\hline & 0.013 & 0.004 & 0.010 & 0.004 & 0.003 \\
\hline \multirow[t]{2}{*}{ Market-to-Book } & 0.004 & 0.000 & $0.002 * * *$ & 0.001 & 0.001 \\
\hline & 0.003 & 0.000 & 0.000 & 0.002 & 0.000 \\
\hline \multirow[t]{2}{*}{ Leverage Ratio } & $-0.115 * * *$ & 0.014 & $-0.108 * * *$ & 0.005 & $0.027 *$ \\
\hline & 0.028 & 0.009 & 0.022 & 0.018 & 0.016 \\
\hline \multirow[t]{2}{*}{ Operating cash flow/lagged assets } & $-0.082 *$ & 0.014 & $0.025 * *$ & $-0.126 * * *$ & $-0.014 *$ \\
\hline & 0.044 & 0.009 & 0.013 & 0.036 & 0.007 \\
\hline \multirow[t]{2}{*}{ Size } & $-0.002 * * *$ & $0.001 *$ & $-0.004 * * *$ & 0.001 & 0.000 \\
\hline & 0.001 & 0.000 & 0.001 & 0.000 & 0.000 \\
\hline Additional Control Variables & Yes & Yes & Yes & Yes & Yes \\
\hline $\mathrm{N}$ & 20,732 & 21,704 & 20,862 & 21,885 & 21,885 \\
\hline $\mathrm{R}^{2}$ & 0.126 & 0.063 & 0.154 & 0.085 & 0.012 \\
\hline
\end{tabular}




\section{Table V}

\section{The relation between change in investment and increase in risk}

This table presents the relation between increase in risk and investment in the year following covenant violations. Increase in Risk is 1 if next year's risk is higher than current year's risk, adjusted by 2-digit SIC industry median, and 0 otherwise. Change in Total Investment is equal to the difference of total investment scaled by lagged assets from the quarter of the violation to one year after the violation. First Time equals one if it is the first time a firm violates a covenant. Repeat equals one if it is not the first time the firm violates a covenant. All specifications include industry, year fixed effects, lagged first difference covenant control variables, first difference covenant control variables, and higher order covenant control variables. Additional control variables are described in Table III. The sample is limited to firms-quarter observations in the fourth quarter of each year. Standard errors are clustered by firm. *, **, and *** indicate significance at the $10 \%, 5 \%$, and $1 \%$ levels, respectively.

\begin{tabular}{|c|c|c|}
\hline & $\begin{array}{c}\text { Change } \\
\text { in Total } \\
\text { Investment }\end{array}$ & $\begin{array}{c}\text { Change } \\
\text { in Total } \\
\text { Investment }\end{array}$ \\
\hline \multirow[t]{2}{*}{ Intercept } & $0.034 * *$ & $0.032 * *$ \\
\hline & 0.015 & 0.014 \\
\hline \multirow[t]{2}{*}{ New Financial Covenant Violation } & $-0.029 * * *$ & \\
\hline & 0.007 & \\
\hline \multirow[t]{2}{*}{ Increase in Risk } & $-0.010 * * *$ & \\
\hline & 0.002 & \\
\hline \multirow[t]{2}{*}{ Increase in Risk* New Viol } & $0.028 * * *$ & \\
\hline & 0.010 & \\
\hline \multirow[t]{2}{*}{ Increase in Risk* New Viol * First Time } & & $0.026 * *$ \\
\hline & & 0.011 \\
\hline \multirow[t]{2}{*}{ Increase in Risk* New Viol * Repeat } & & 0.016 \\
\hline & & 0.021 \\
\hline \multirow[t]{2}{*}{ First Time } & & $-0.031 * * *$ \\
\hline & & 0.008 \\
\hline \multirow[t]{2}{*}{ Repeat } & & $-0.023 *$ \\
\hline & & 0.013 \\
\hline \multirow[t]{2}{*}{ Market-to-Book } & 0.004 & 0.004 \\
\hline & 0.003 & 0.003 \\
\hline \multirow[t]{2}{*}{ Leverage Ratio } & $-0.120 * * *$ & $-0.114 * * *$ \\
\hline & 0.029 & 0.028 \\
\hline \multirow[t]{2}{*}{ Operating cash flow/lagged assets } & $-0.087 *$ & $-0.081 *$ \\
\hline & 0.044 & 0.044 \\
\hline \multirow[t]{2}{*}{ Size } & $-0.002 * *$ & $-0.002 * * *$ \\
\hline & 0.001 & 0.001 \\
\hline Additional Control Variables & Yes & Yes \\
\hline $\mathrm{N}$ & 20,735 & 20,735 \\
\hline $\mathrm{R}^{2}$ & 0.128 & 0.126 \\
\hline
\end{tabular}




\section{Table VI}

The risk-shifting activities of the firms before and after the violation year

This table presents the risk-shifting activities of firms which violate a covenant once during the sample period. Change in Risk is equal to the natural logarithm of 1+IRAR. Change in Total Investment is equal to the difference of total investment scaled by lagged assets from the quarter of the violation to one year after the violation. All specifications include industry, year fixed effects, lagged first difference covenant control variables, first difference covenant control variables and higher order covenant control variables. Additional control variables are described in Table II. The sample is limited to firms-quarter observations in the fourth quarter of each year. The first column includes all years before the violation. The second column shows the investment-risk relation in year before the violation. The third column shows the investment-risk relation in the year following the violation. Standard errors are clustered by firm. *, **, and *** indicate significance at the $10 \%, 5 \%$, and $1 \%$ levels, respectively.

\begin{tabular}{|c|c|c|c|}
\hline & $\begin{array}{c}\text { Before the } \\
\text { violation } \\
\text { Change in } \\
\text { Total } \\
\text { Investment }\end{array}$ & $\begin{array}{c}\text { One year before } \\
\text { the violation } \\
\text { Change in } \\
\text { Total } \\
\text { Investment }\end{array}$ & $\begin{array}{c}\text { After the } \\
\text { violation } \\
\text { Change in } \\
\text { Total } \\
\text { Investment }\end{array}$ \\
\hline \multirow[t]{2}{*}{ Change in Risk } & $-0.018 * *$ & $-0.037 *$ & $0.013^{*}$ \\
\hline & 0.007 & 0.021 & 0.060 \\
\hline \multirow[t]{2}{*}{ Market-to-Book } & 0.006 & 0.003 & 0.030 \\
\hline & 0.005 & 0.006 & 0.027 \\
\hline \multirow[t]{2}{*}{ Leverage Ratio } & $-0.190 * * *$ & $-0.090 * *$ & -0.039 \\
\hline & 0.060 & 0.041 & 0.107 \\
\hline \multirow[t]{2}{*}{ Operating cash flow/lagged assets } & $0.240 * * *$ & 0.050 & $-0.279 * *$ \\
\hline & 0.059 & 0.165 & 0.129 \\
\hline \multirow[t]{2}{*}{ Size } & -0.002 & $-0.019 * * *$ & -0.003 \\
\hline & 0.001 & 0.006 & 0.003 \\
\hline Additional Control Variables & Yes & Yes & Yes \\
\hline $\mathrm{N}$ & 2,197 & 1,001 & 1,389 \\
\hline $\mathrm{R}^{2}$ & 0.057 & 0.051 & 0.147 \\
\hline
\end{tabular}


Table VII

The relation between change in investment and change in risk for financially constrained firms This table presents the relation between risk and investment following covenant violations for financially constrained firms at the year following the violation. Change in Risk is equal to the natural logarithm of 1+IRAR. Change in Total Investment is equal to the difference of total investment scaled by lagged assets from the quarter of the violation to one year after the violation. A firm is financially constraint if the Whited and $\mathrm{Wu}$ (2006) index is in the upper third of the distribution. All specifications include industry, year fixed effects, lagged first difference covenant control variables, first difference covenant control variables and higher order covenant control variables. Additional control variables are described in Table III. The sample is limited to firms-quarter observations in the fourth quarter of each year. Standard errors are clustered by firm. *, **, and *** indicate significance at the $10 \%, 5 \%$, and $1 \%$ levels, respectively.

\begin{tabular}{|c|c|}
\hline & $\begin{array}{c}\text { Change } \\
\text { in Total } \\
\text { Investment }\end{array}$ \\
\hline New Financial Covenant Violation & $\begin{array}{l}-0.017 \text { *** } \\
0.005\end{array}$ \\
\hline Change in Risk & $\begin{array}{l}-0.013^{* * *} \\
0.003\end{array}$ \\
\hline Change in Risk* New Viol & $\begin{array}{l}0.025 * * \\
0.012\end{array}$ \\
\hline Change in Risk $*$ New Viol $*$ Financially Constrained & $\begin{array}{l}0.034^{*} \\
0.020\end{array}$ \\
\hline Financially Constrained & $\begin{array}{r}-0.003 \\
0.004\end{array}$ \\
\hline Change in Risk * Financially Constrained & $\begin{array}{r}-0.002 \\
0.008\end{array}$ \\
\hline Financially Constrained $*$ New Viol & $\begin{array}{l}0.002 \\
0.008\end{array}$ \\
\hline Market-to-Book & $\begin{array}{l}0.002 \\
0.001\end{array}$ \\
\hline Leverage Ratio & $\begin{array}{l}-0.102 \text { *** } \\
0.015\end{array}$ \\
\hline Operating cash flow/lagged assets & $\begin{array}{r}-0.017 \\
0.020\end{array}$ \\
\hline Size & $\begin{array}{l}-0.003 * * * \\
0.001\end{array}$ \\
\hline Additional Control Variables & Yes \\
\hline $\mathrm{N}$ & 20,463 \\
\hline $\mathrm{R}^{2}$ & 0.152 \\
\hline
\end{tabular}




\section{Table VIII}

\section{The effect of managerial risk incentives on risk-taking behavior}

This table presents the relation between risk and investment in the year following covenant violations for firms with high managerial risk taking incentives. Increase in Risk is 1 if next year's risk is higher than current year's risk, adjusted by 2-digit SIC industry median, and 0 otherwise A firm is a High Vega (High Delta) firm if vega (delta) is higher than the sample mean. A firm is considered to be a High Managerial Ownership firm if the percentage of equity owned by the CEO is higher than the sample median. The dependent variable is the change in investment. All specifications include industry, year fixed effects, lagged first difference covenant control variables, first difference covenant control variables, higher order covenant control variables, two-way interaction variables. Additional control variables are described in Table III. The sample is limited to firms-quarter observations in the fourth quarter of each year. The twoway interaction variables are also included in the tests but not reported. Standard errors are clustered by firm. *, **, and $* * *$ indicate significance at the $10 \%, 5 \%$, and $1 \%$ levels, respectively.

\begin{tabular}{|c|c|c|}
\hline & $\begin{array}{c}\text { CEO } \\
\text { Wealth } \\
\text { Sensitivity }\end{array}$ & $\begin{array}{c}\text { CEO } \\
\text { Equity } \\
\text { Ownership }\end{array}$ \\
\hline New Financial Covenant Violation & $\begin{array}{r}-0.035 \\
0.031\end{array}$ & $\begin{array}{l}-0.026 * * * \\
0.007\end{array}$ \\
\hline Increase in Risk & $\begin{array}{l}0.002 \\
0.006\end{array}$ & $\begin{array}{l}-0.007 * * * \\
0.002\end{array}$ \\
\hline Increase in Risk* NewViol & $\begin{array}{l}0.082 * \\
0.047\end{array}$ & $\begin{array}{l}0.013 * \\
0.008\end{array}$ \\
\hline Increase in Risk * NewViol * High Managerial Ownership Dummy & & $\begin{array}{l}0.020 * * \\
0.003\end{array}$ \\
\hline High Managerial Ownership Dummy & & $\begin{array}{l}0.005 \\
0.003\end{array}$ \\
\hline Increase in Risk * NewViol * High Vega Dummy & $\begin{array}{l}0.028 * * \\
0.014\end{array}$ & \\
\hline Increase in Risk * NewViol * High Delta Dummy & $\begin{array}{c}-0.022 * \\
0.013\end{array}$ & \\
\hline High Vega Dummy & $\begin{array}{r}-0.008 \\
0.005\end{array}$ & \\
\hline High Delta Dummy & $\begin{array}{l}0.005 \\
0.006\end{array}$ & \\
\hline Market-to-Book & $\begin{array}{r}-0.003 \\
0.003\end{array}$ & $\begin{array}{l}0.000 \\
0.002\end{array}$ \\
\hline Leverage Ratio & $\begin{array}{r}-0.054 \\
0.040\end{array}$ & $\begin{array}{l}-0.103 * * * \\
0.018\end{array}$ \\
\hline Operating cash flow/lagged assets & $\begin{array}{l}0.145 \\
0.108\end{array}$ & $\begin{array}{r}-0.052 \\
0.039\end{array}$ \\
\hline Size & $\begin{array}{r}-0.002 \\
0.001\end{array}$ & $\begin{array}{r}-0.002 \\
0.001\end{array}$ \\
\hline Additional Control Variables & Yes & Yes \\
\hline $\begin{array}{l}\mathrm{N} \\
\mathrm{R}^{2}\end{array}$ & $\begin{array}{l}4,513 \\
0.228\end{array}$ & $\begin{array}{l}8,274 \\
0.156\end{array}$ \\
\hline
\end{tabular}


Table IX

Financial Covenant Violations and Firm Risk

This table presents the estimates of the marginal effect of covenant violation on firm risk from the quarter of the violation to one year after the violation. All the dependent variables except Change in Asset Volatility are the natural logarithm of the ratio of next year's firm risk to current year's firm risk. Change in Asset Volatility is the natural logarithm of 1+IRAR. Asset Volatility is derived from Moody's KMV method. Earnings Volatility is the standard deviation of a firm's return on assets (ROA) over 12 quarterly observations. Total Risk is annualized standard deviation of daily returns over the fiscal year. Systematic Risk is the standard deviation of the product of the firm beta times the market daily returns. Unsystematic Risk is annualized standard deviation of the residuals from the market model. Asset Beta is the calculated by unlevering the equity beta which is derived from the market model. All specifications include industry, year fixed effects, lagged first difference covenant control variables, first difference covenant control variables and higher order covenant control variables. Additional control variables are described in Table III. The sample is limited to firms-quarter observations in the fourth quarter of each year. Standard errors are clustered by firm. *, **, and *** indicate significance at the $10 \%, 5 \%$, and $1 \%$ levels, respectively.

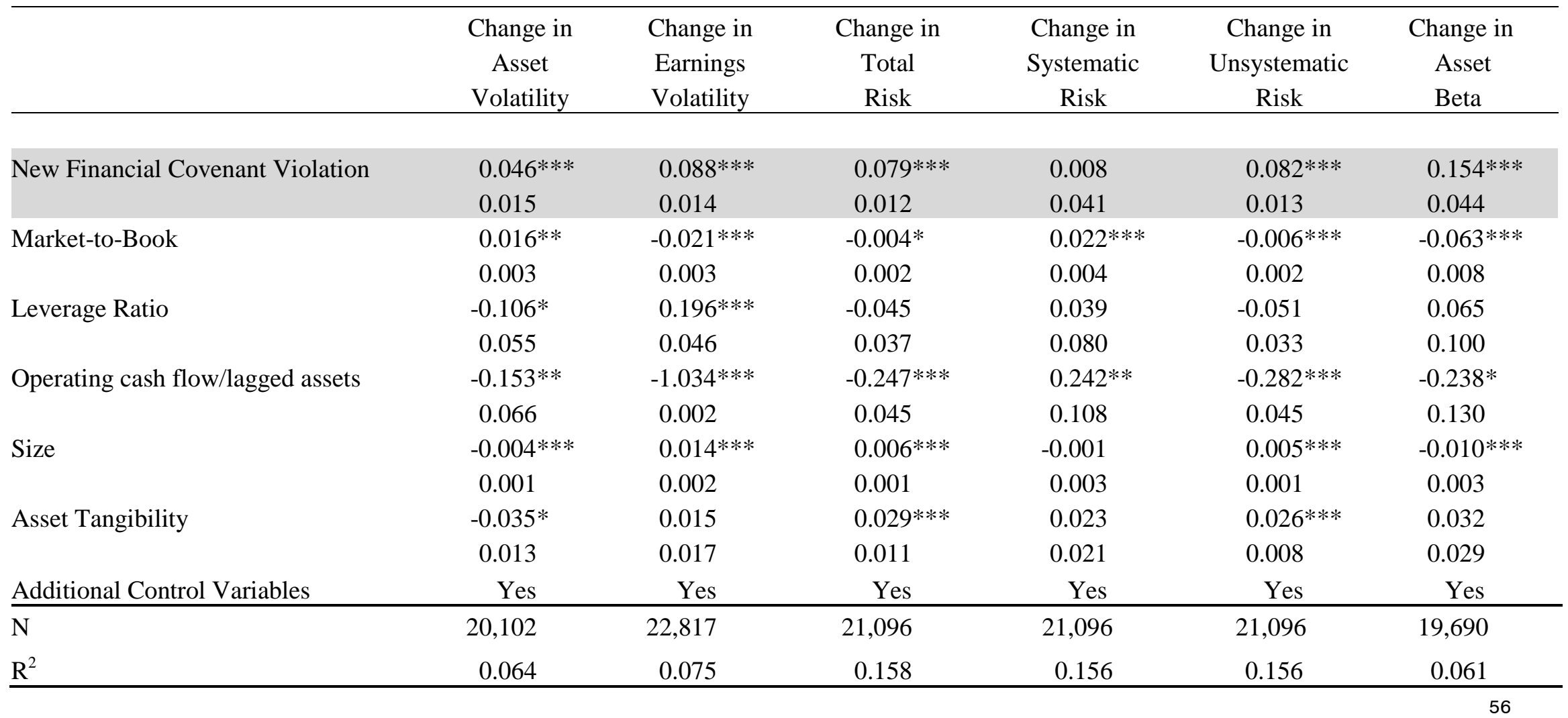


Table X

The relation between change in investment and change in risk using analysts' forecasts dispersion

This table presents the relation between risk and investment following covenant violation. Expected Volatility is the standard deviation of $\mathrm{I} / \mathrm{B} / \mathrm{E} / \mathrm{S}$ earnings per share forecasts for the next fiscal year end, scaled by the absolute value of the mean estimate. Change in Total Investment (Capital Expenditure) is the change in total investment (capital expenditure) in the following year. All specifications include industry, year fixed effects, lagged first difference covenant control variables, first difference covenant control variables and higher order covenant control variables. Additional control variables are described in Table III. The sample is limited to firms-quarter observations in the fourth quarter of each year. Standard errors are clustered by firm. *, **, and *** indicate significance at the $10 \%, 5 \%$, and $1 \%$ levels, respectively.

\begin{tabular}{lcc}
\hline & $\begin{array}{c}\text { Change } \\
\text { in Total } \\
\text { Investment }\end{array}$ & $\begin{array}{c}\text { Change } \\
\text { in Capital } \\
\text { Expenditure }\end{array}$ \\
\hline New Financial Covenant Violation & & \\
Expected Volatility & -0.014 & $-0.024^{* *}$ \\
& 0.009 & 0.005 \\
Expected Volatility * NewViol & $-0.005^{* * *}$ & $-0.002^{* * *}$ \\
& 0.001 & 0.000 \\
Market-to-Book & $0.006^{* *}$ & $0.003^{* *}$ \\
Leverage Ratio & 0.003 & 0.001 \\
& $0.020^{* * *}$ & 0.002 \\
Operating cash flow/lagged assets & 0.005 & 0.001 \\
Size & $-0.082^{* * *}$ & -0.014 \\
& 0.030 & 0.013 \\
Additional Control Variables & $-0.148^{* *}$ & -0.012 \\
$\mathrm{~N}$ & 0.069 & 0.018 \\
$\mathrm{R}^{2}$ & $-0.002^{* *}$ & $0.002^{* * *}$ \\
\hline
\end{tabular}




\section{Table XI}

The relation between change in investment and change in risk using a matched sample

This table presents the relation between risk and investment following covenant violation using a matched sample. Every year, each violator firm is matched to a non-violator firm in the 2-digit SIC industry and size decile, with closest book-to-market ratio. Change in Risk is equal to the natural logarithm of 1+IRAR. Change in Total Investment is equal to the difference of total investment scaled by lagged assets from the quarter of the violation to one year after the violation. Change in Capital Expenditure is equal to the difference of capital expenditure scaled by lagged assets from the quarter of the violation to one year after the violation All specifications include industry, year fixed effects, lagged first difference covenant control variables, first difference covenant control variables and higher order covenant control variables. Additional control variables are described in Table III. The sample is limited to firms-quarter observations in the fourth quarter of each year. Standard errors are clustered by firm. $* * *$, and $* * *$ indicate significance at the $10 \%, 5 \%$, and $1 \%$ levels, respectively.

\begin{tabular}{|c|c|c|}
\hline & $\begin{array}{c}\text { Change } \\
\text { in Total } \\
\text { Investment }\end{array}$ & $\begin{array}{c}\text { Change } \\
\text { in Capital } \\
\text { Expenditure }\end{array}$ \\
\hline \multirow[t]{2}{*}{ New financial Violation } & -0.003 & -0.005 \\
\hline & 0.007 & 0.004 \\
\hline \multirow[t]{2}{*}{ Change in Risk } & $-0.015 * * *$ & $-0.013 * * *$ \\
\hline & 0.001 & 0.005 \\
\hline \multirow[t]{2}{*}{ Change in Risk* NewViol } & $0.027 * *$ & $0.018 * * *$ \\
\hline & 0.014 & 0.007 \\
\hline \multirow[t]{2}{*}{ Market-to-Book } & -0.010 & 0.000 \\
\hline & 0.015 & 0.007 \\
\hline \multirow[t]{2}{*}{ Leverage Ratio } & -0.042 & -0.032 \\
\hline & 0.075 & 0.035 \\
\hline \multirow[t]{2}{*}{ Operating cash flow/lagged assets } & -0.017 & 0.068 \\
\hline & 0.136 & 0.052 \\
\hline \multirow[t]{2}{*}{ Size } & -0.003 & -0.001 \\
\hline & 0.002 & 0.001 \\
\hline Additional Control Variables & Yes & Yes \\
\hline $\mathrm{N}$ & 2,280 & 2,280 \\
\hline $\mathrm{R}^{2}$ & 0.284 & 0.212 \\
\hline
\end{tabular}




\section{Figure 1}

The top panel of this figure presents annualized mean of stock return volatility around a new financial covenant violation. Stock return volatility is the annualized standard deviation of stock prices calculated using 180-day window, normalized by market volatility over the same period. The bottom panel plots the mean earnings volatility normalized by 2 digit SIC industry median over the same period. Earnings volatility is the standard deviation of return on assets (ROA) scaled by lagged assets using 3-year window.
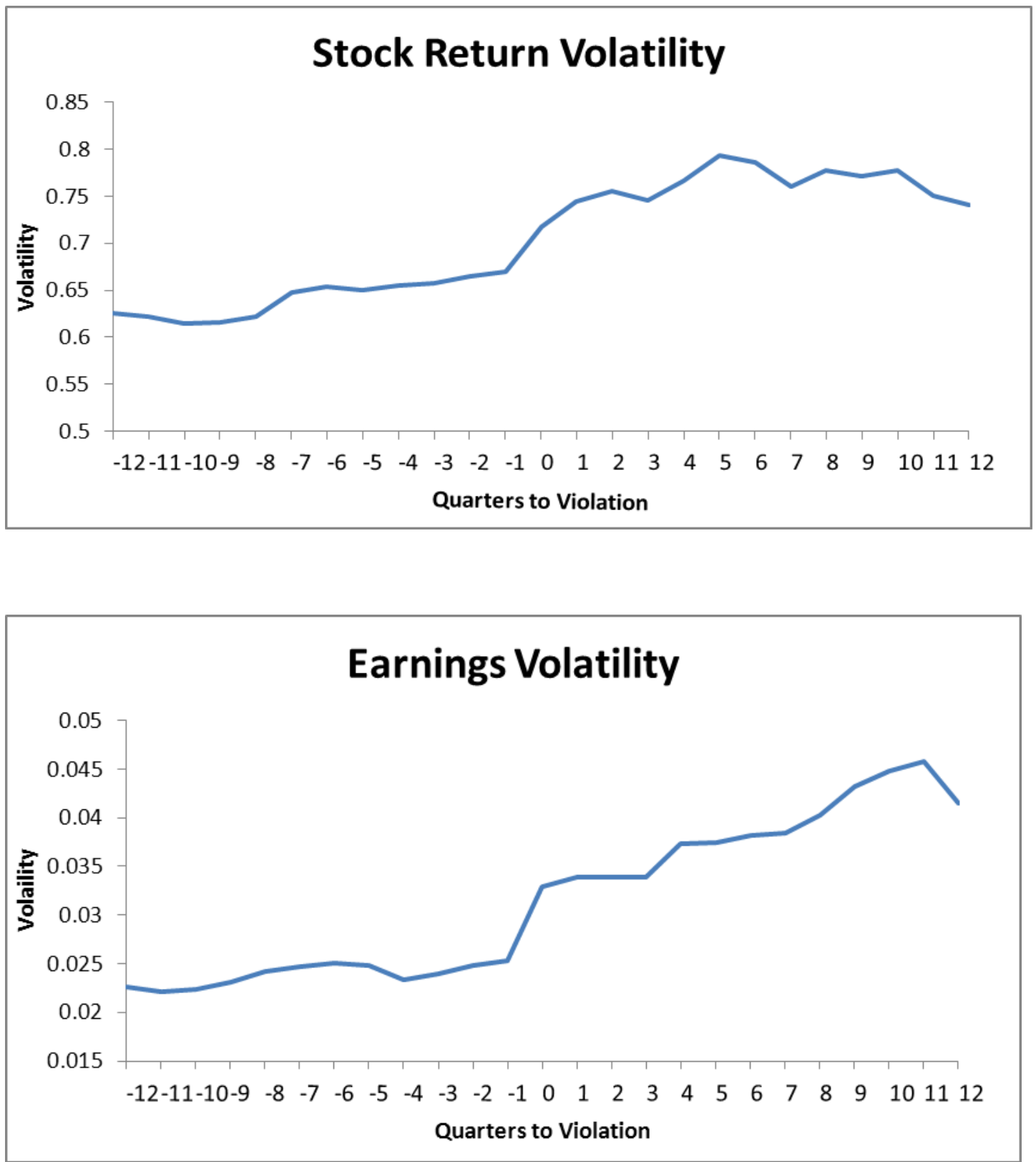